\title{
AS ARTES E OS OFÍCIOS DE UM LETRADO AFRO-DIASPÓRICO: ELISEU CÉSAR (1871-1923)
}

\author{
Solange Pereira da Rocha ${ }^{1}$ \\ Petrônio Domingues ${ }^{2}$ \\ Elio Chaves Flores ${ }^{3}$
}

ábado, 27 de janeiro de 1923. Os jornais do Rio de Janeiro, a capital da República, repercutiram o falecimento de Eliseu César. "Uma inesperada e triste notícia surpreendeu, hoje, às primeiras horas da manhã: morreu pela madrugada, repentinamente, Eliseu César", noticiou A Rua. "Não é possível traduzir a emoção que por toda a parte provocou essa dolorosa novidade"; Eliseu César era uma "figura de grande relevo, quer na imprensa, quer nos meios jurídicos e, ainda, nos meios políticos", concluiu a reportagem. ${ }^{4}$ Outro diário, A Noite, também salientou que o passamento de Eliseu César foi recebido pela população carioca com perplexidade: "Ainda ontem o extinto estivera trabalhando normalmente, recolhendo-se à sua residência justamente à hora em que habitualmente o fazia". No entanto às $2 \mathrm{~h} 30$ da madrugada ele despertou, "sentindo

1 Doutora em História pela Universidade Federal de Pernambuco (UFPE) e professora associada da Universidade Federal da Paraíba (UFPB). banto20ufpb@gmail.com

2 Doutor em História pela Universidade de São Paulo (USP), professor associado da Universidade Federal de Sergipe (UFS).pjdomingues@yahoo.com.br

3 Doutor em História pela Universidade Federal Fluminense (UFF), professor titular da Universidade Federal da Paraíba (UFPB). eliochavesflores@gmail.com

4 "Morreu hoje o dr. Elyseu Cezar", A Rua, Rio de Janeiro, 27/01/1923, p. 3. Destacamos que todos os jornais citados neste artigo pertencem ao acervo da Biblioteca Nacional (RJ). 
asfixia, uma crise julgada passageira, mas tão grave que não deu tempo à sua família para procurar recursos médicos. Em poucos momentos o Dr. Eliseu César expirava". 5 De acordo com a Gazeta de Notícias, todos avaliavam que "aquele porte varonil, rico de vida e de espírito, estivesse em pleno vigor da saúde. Infelizmente, não era assim". ${ }^{6}$

Eliseu César era retratado como um "homem de ação, trabalhador infatigável, defensor dos humildes", que "merecia a larga estima que desfrutava em todas as camadas sociais". 7 Talvez tenha sido por isso que, segundo o Jornal do Brasil, às derradeiras homenagens prestadas ao "ilustre morto" associaram-se seus amigos, admiradores, "várias associações de classe e grande número de familiares do bairro de São Cristóvão". Ao velório "acorreram muitos amigos e colegas, a fim de apresentar à família enlutada suas demonstrações de pesar". O enterro ocorreu no domingo pela manhã, "saindo o féretro às $8 \mathrm{~h} 00$ da residência da família, à Rua Tuiuti, no 61, em São Cristóvão". Formou-se um "grande cortejo" em direção ao cemitério São Francisco Xavier. Chegando o corpo à necrópole, seus amigos, num gesto que bem expressava o "grau de amizade e admiração pelo extinto, não permitiram o sepultamento em cova rasa e, cotizando-se, adquiriram carneiro perpétuo". ${ }^{8}$

Por ocasião de baixar o ataúde ao túmulo, fizeram-se ouvir vários oradores, que "realçaram as qualidades de Eliseu César como homem de trabalho, como chefe de família e como amigo". Os discursos "causaram funda impressão em todos os presentes". Em meio ao clima lúgubre, ramalhetes de flores foram lançados sobre o caixão. Muitas pessoas compareceram às exéquias. A imprensa registrou a presença de familiares, populares, representantes da Associação Nacional dos Artistas Brasileiros, do Centro Republicano Popular, da Associação do Foro; estudantes, rábulas e advogados (como Evaristo de Moraes, João da Costa Pinto e José Anísio), jornalistas (como Raul Pederneiras, Silvino Rolim e Oscar de Carvalho), militares (como o tenente Elídio Moura, o capitão José Joaquim Osório e o coronel Euzébio Martins da Rocha),

5 "Seu falecimento, hoje, nesta capital", A Noite, Rio de Janeiro, 27/01/1923, p. 5.

6 "A morte do brilhante jornalista e advogado", Gazeta de Notícias, Rio de Janeiro, 28/01/1923, p. 3.

7 "Morreu hoje o dr. Elyseu Cezar", p. 3.

8 "Enterros", Jornal do Brasil, Rio de Janeiro, 30/01/1923, p. 10. 
intendentes municipais (como Nogueira Penido), deputados (como Artur Lemos e Antônio Camilo de Holanda), um representante do ministro da Justiça (major Carlos Reis), um ministro do Supremo Tribunal Federal (Geminiano da Franca), entre outras autoridades públicas. A viúva recebeu diversos telegramas de condolências: "Ao querido Eliseu, último adeus de Benedito e família"; "Saudades dos seus amigos da Inspetoria de Investigação"; "Gratidão de sua afilhada Ariete". 9

Quem era esse sujeito que foi visto pelo jornal O Paiz como o "sucessor autêntico e racial de [José do] Patrocínio", ${ }^{10}$ quando não chamado de "o preto magnífico"?"11 Que foi definido pelo padre Olympio de Castro - o capelão da Igreja de Nossa Senhora do Rosário e São Benedito dos Homens Pretos - como o "Rui Barbosa negro"?12 Quem era aquele sujeito que, de acordo com a Gazeta de Notícias, gozava de "grande" popularidade na cidade do Rio de Janeiro? ${ }^{13}$ E cujo falecimento despertou a atenção de alguns dos principais veículos de comunicação da Capital da República? A finalidade deste artigo é reconstituir fragmentos da trajetória de vida de Eliseu César, privilegiando suas venturas e desventuras na esfera pública. A intenção aqui é começar a tecer os fios da história de um "homem de cor" que, embora procedente de uma família que remonta à época da escravidão, passou pela experiência de mobilidade social e reconhecimento cultural, vivendo de forma pungente os desafios,

9 "Enterros", p. 10; "Ministério da Justiça", O Paiz, Rio de Janeiro, 30/01/1923, p. 4.

10 "Autores e livros", O Paiz, Rio de Janeiro, 9 jun. 1926, p. 1. José do Patrocínio (1854-1905) foi um jornalista, escritor, político abolicionista e orador afro-brasileiro nascido no Rio de Janeiro, na cidade de Campos dos Goitacazes. Aos quinze anos mudou-se para a capital do Império, onde se diplomou em Farmácia, dedicou-se às atividades jornalísticas, publicou livros e se destacou no movimento abolicionista como uma das lideranças mais combativas, polemistas e talentosas na arte da retórica. Em 1886, foi eleito para a Câmara Municipal e cumpriu um papel importante, tanto no episódio da abolição da escravidão, em 13 de maio de 1888, quanto na Proclamação da República, em 15 de novembro de 1889.

11 "Política do Distrito", O Paiz, Rio de Janeiro, 28/12/1923, p. 4.

12 " $10^{\circ}$ Manifesto do Centro da Federação dos Homens de Cor às classes proletárias", O Paiz, Rio de Janeiro, 25/01/1924, p. 4. Rui Barbosa (1849-1923) foi um advogado, jornalista, jurista e político, nascido em Salvador, Bahia, e falecido na cidade de Petrópolis, no Rio de Janeiro. Trabalhou em diversos jornais da imprensa regular. Em 1878, foi eleito representante da Bahia no Parlamento do Império, no Rio de Janeiro, onde fez carreira política atuando em prol da causa abolicionista e republicana, assumindo cargos de senador e ministro da Fazenda no primeiro governo da República, sem falar que se candidatou duas vezes para presidente do Brasil (1910 e 1919) sem êxito. Era considerado um exímio orador.

13 "A morte do brilhante jornalista e advogado", p. 3. 
os impasses e as encruzilhadas relacionadas à afirmação da cidadania negra no período pós-abolição.

A trajetória de Eliseu César é expressiva de um intelectual afro-diaspórico, pois não é improvável que seus avós maternos tenham atravessado o Atlântico. Com efeito, antes de inquirir "comunidades transatlânticas" nas Américas, a questão é entender que os legados coloniais nas sociedades racializadas, como a nossa, "podem forçar as pessoas a migrar, o que causa o espalhamento - a dispersão". ${ }^{14}$ Podemos pensar que contingências, indeterminações e precariedades estiveram no cotidiano sentido à flor da pele por Eliseu César. Assim, "modernidade e dupla consciência" podiam estar no horizonte de expectativas de um "homem de cor" que atravessou a Monarquia para a República e, embora não tenha conseguido se desvencilhar da "metafísica da raça", ${ }^{15}$ projetou-se na esfera pública a partir, sobretudo, de duas dimensões de sua experiência: a letra e a voz.

\section{Nas paragens paraibanas}

Aos dezessete de dezembro de 1871, nesta paroquial Igreja de Nossa Senhora das Neves, batizei solenemente o párvulo Elizeô, pardo, com cinco meses de idade, filho natural de Maria Joaquina de Freitas, solteira, moradora nesta freguesia, sendo padrinhos o Capitão Caetano Daniel de Carvalho e sua mulher, Dona Silvana Augusta Pessoa de Carvalho, todos moradores desta freguesia. E para constar mandei fazer [este] assento que assino. Vigário Francisco de Paula Mello Cavalcanti. (Grifos nossos) ${ }^{16}$

14 Stuart Hall, Da diáspora: identidades e mediações culturais, Belo Horizonte: Editora da UFMG, 2002, p. 28.

15 No prefácio à edição brasileira de sua principal obra, Paul Gilroy assim escreveu: "Falar do Brasil produz, corretamente, hesitação. Tudo o que normalmente eu quero dizer sobre a cultura e a mistura, a diáspora, a história e a sociabilidade transafricana tem uma ressonância diferente quando se refere a um lugar tão próximo do epicentro da escravidão racial moderna", em Paul Gilroy, OAtlântico negro: modernidade e dupla consciência, São Paulo: Editora 34, 2003, p. 10.

16 O assento de batismo de Eliseu E. César encontra-se no Livro de Batismo 7 (1871-1875), da freguesia de Nossa Senhora das Neves (capital da Paraíba), folha 47-frente, no Arquivo Eclesiástico da Arquidiocese da Paraíba (AEAPB). 
Eliseu César nasceu na cidade da Parahyba (denominada atualmente de João Pessoa), então capital de uma das províncias do norte, em 21 de julho de 1871. Conforme consta no seu assento batismal, apesar de ter nascido dois meses antes da aprovação da Lei Rio Branco (mais conhecida como Lei do Ventre Livre, promulgada em 28 de setembro de 1871), ele e sua mãe não eram escravizados. Se a situação fosse diferente, constaria no documento paroquial a condição de escrava de sua genitora, seguida do nome de seu proprietário. Na sociedade escravista, o assento batismal era importante para se comprovar o estatuto jurídico da pessoa - se "escrava", liberta ou livre -, mesmo porque, no contexto provincial, não era incomum a "liberdade interditada por cativeiro ilícito". ${ }^{17}$

No dia 17 de dezembro de 1871, Maria Joaquina de Freitas, uma mulher "solteira", conforme consta no documento paroquial, levou à pia batismal, depois de cinco meses de nascido, seu filho que tinha por nome "Elizêo" e era identificado como "pardo". Este foi apadrinhado por um casal com alguma posse social e econômica: Caetano Daniel de Carvalho - considerado por alguns como um rico comerciante, que detinha a patente de “capitão", provavelmente da Guarda Nacional - e sua consorte, Silvana Augusta Pessoa de Carvalho, referida como uma "dona", termo da época para indicar prestígio de uma mulher na sociedade oitocentista. Tendo como referência o Recenseamento de 1872, a cidade da Parahyba contava com 24.714 habitantes, dos quais mais de 50\% eram classificados como "pardos" e "pretos". Em toda a província, a população com ascendência africana correspondia a 59\% dos 376.226 habitantes, o que demonstra como Eliseu nasceu em um lugar com insofismável presença negra.

Quanto ao seu pai, consta que se chamava Dulcídio Augusto César, fazia parte dos $38,5 \%$ da população branca da província ${ }^{18}$ e teria

17 Maria da Vitória Barbosa Lima, Liberdade interditada, liberdade reavida: escravos e libertos na Paraíba escravista (século XIX), Brasília: Fundação Cultural Palmares, 2013, pp. 297-312.

18 Solange P. Rocha, "População, compadrio e trajetórias de gente negra na cidade da Paraíba oitocentista", Saeculum: Revista de História, n. 33 (2015), pp. 184-187; "Eliseu Elias César, de tipógrafo a literato: memórias e história de um letrado negro (1871-1923)", in Solange P. Rocha e Matheus Silveira Guimarães (orgs.), Travessias Atlânticas e a Paraiba Afro-diaspórica: experiências da gente negra na diáspora africana. Paraíba Colonial e Imperial - volume 1 (João Pessoa: Editora da UFPB, 2019), pp. 347-373. Cf. também Julio César P. dos Santos, “"Preto no Branco': a trajetória do paraibano Elyseu Elias César no pós-abolição" (Dissertação de Mestrado, Universidade Federal de Pernambuco, 2019). 
assumido posicionamentos abolicionistas. O "moleque Eliseu" não foi criado pela mãe, cujo destino permanece desconhecido, mas pela avó materna, Vicência Ferreira de Albuquerque César, que o acolheu no seu "lar virtuoso. Criou-o com o maior desvelo. Mandou-o para a escola. Ensinou-lhe religião, sentimentos". ${ }^{19}$ Eliseu teria percorrido uma rápida formação letrada, tendo feito o "preparatório" no Lyceu Paraibano. ${ }^{20}$ Caminhada espinhosa e incomum para criança e, depois, jovem negro na última década da escravidão no Brasil.

Cedo começou a trabalhar como tipógrafo e, mais tarde, "praticante dos Correios". Ser tipógrafo requeria um aprendizado dos mestres do ofício, que facilitava o contato com as palavras e com as leituras das provas tipográficas. Os tipos móveis, com os quais se iniciava o processo tipográfico, permitiam aos aprendizes a sedução pelas ideias e argumentos quando iam para a prensa a vincarem palavras e frases nos papéis previamente formatados para pasquins e edições literárias. Além de tipógrafo, o ofício gráfico exigia artífices como distribuidor, impressor, encadernador e, talvez, os que exigissem mais experiência, o chefe de oficina e o revisor. Parece ter sido nesse espaço de aprendizes e artífices, embebidos de tipos móveis, provas e impressões, que Eliseu ganhou gosto pelo mercado das letras nas oficinas dos jornais da Parahyba do Norte.

Na edição de 26 de setembro de 1891, O Estado da Parayba publicava a seguinte notícia: "Foi nomeado praticante dos Correios d'este Estado o mavioso poeta Eliseu Cesar, distinto colaborador da parte poética desta folha". No segundo parágrafo da matéria, o jornal destacava: "folgamos em reconhecer no nomeado as aptidões precisas para exercer com critério e inteligência o referido cargo". Foram nomeados mais três praticantes e dois carteiros. ${ }^{21}$ Se o edital do concurso exigia do candidato

19 Seráphico Nóbrega, "Discurso de Posse na Academia Paraibana de Letras", Revista Academia Paraibana de Letras, n. 6 (1955), pp. 275-302.

20 "Exames de preparatórios", Gazeta da Parayba, Parayba do Norte, 11/11/1888, pp. 1-3. Sobre a educação da população negra na Parahyba do Norte nesse período, cf. Surya Aaronovich Pombo de Barros, "Universo letrado, educação e população negra na Parahyba do Norte (século XIX)" (Tese de Doutorado, Universidade de São Paulo, 2017).

21 "Eliseu Cesar", O Estado da Parahyba: Periódico Político, Social e Noticioso, Parahyba do Norte, 03/07/1891. Chamou-nos atenção para a grafia do nome, porque se percebeu que a adotada em todas as poesias é Elizeu Cezar. Apenas em duas ocasiões ele assina E. E. Cezar. As variações aparecem a partir de outros redatores, revisores ou tipógrafos: Elyseu Cezar, 
para a função pública de "carteiro" capacidade de leitura, escrita e domínio das quatro operações da aritmética, para "praticante" os requisitos eram maiores e a função mais bem remunerada. Exigia-se que o candidato tivesse amplo domínio da cultura letrada: conhecer as línguas portuguesa e francesa; geografia geral e do Brasil; aritmética e teoria das proporções; desenho linear; escrituração mercantil, inglês e alemão. ${ }^{22}$ Para Eliseu, então com vinte anos, o cargo de "praticante dos Correios" lhe permitia ganhar a vida e, ainda, tecer novas redes de sociabilidade, a partir da palavra impressa. Mas não se tratava de qualquer palavra, era preciso "tipografar" aspirações, expectativas e realizar projetos de vida.

O ofício de "praticante dos Correios" predizia o início de um aprendizado de contatos pessoais e alargamento da visão de mundo. Ao que tudo indica, esse segundo ofício também recebeu a influência de seu pai, que chegou a exercer o cargo de administrador dos Correios em duas províncias do norte: a Paraíba e o Rio Grande do Norte. Dulcídio Augusto Cezar pensou em preparar o filho para o "serviço público" e, talvez, para uma carreira que lhe permitisse ascensão social.

Simultaneamente, o jovem Eliseu se lançou ao mundo das letras e das lides jornalísticas. Mesmo a Parahyba do Norte sendo uma "sociedade assaz limitada e pouco dada ao cultivo e apreciação das letras", como assinalava uma revista de crítica e notícias literárias, ${ }^{23} \mathrm{em}$ torno de cinquenta jornais, folhas e pasquins circularam na capital da província durante a década de 1880. Iniciando-se como bardo com apenas dezesseis anos, Eliseu publicou poemas e folhetins em, pelo menos, sete desses jornais - Sorriso (1886-1887), Arauto Parahybano (1888), O Cisne (1889), O Estado (1889/1890), O Parahybano (1892), O Artista (1895) e O Estado do Parahyba (1891-1894), no qual também atuou como colaborador. ${ }^{24}$

Eliseu Elias Cesar e, no português brasileiro atual, parece predominar Eliseu César, grafia adotada aqui.

22 "Edital de concurso para os correios: praticantes e carteiros", O Estado da Parahyba: Periódico Político, Social e Noticioso, Parahyba do Norte, 03/07/1891. O edital segue o Decreto no 9.912 , de 26/03/1888 - Reforma dos Correios do Império. As regras do concurso estão baseadas nos arts. 122 - quadro de funcionários - e 166 - exigências legais.

23 A Idéia: Revista Crítica, Noticiosa e Literária, Parahyba do Norte, 13/12/1879.

24 “A República do mato", O Estado do Parahyba, Parahyba, 06/11/1890, p. 2; "Teus beijos", O Estado do Parahyba, Parahyba, 08/071891, p. 2; "Resignado", O Estado do Parahyba, Parahyba, 29/07/1891, p. 2; "Loucura", O Estado do Parahyba, Parahyba, 12/08/1891, p. 3. 
Em 15 de novembro de 1889, houve a Proclamação da República, o que gerou grandes expectativas - de "expansão de direitos" e "renovação política" - em diversos setores da sociedade (operários, jornalistas, "homens de letras", advogados, intelectuais, militares, políticos, pequenos proprietários, engenheiros, funcionários públicos). A nova forma de governo "despertou entre os excluídos do sistema anterior certo entusiasmo quanto às novas possibilidades de participação". ${ }^{25}$ Eliseu aderiu à causa republicana. Talvez tenha ficado contagiado com a retórica de direitos universais, progresso, civilização e cidadania. ${ }^{26}$ Mas, assim como aconteceu no Rio de Janeiro, onde os intelectuais da "República das Letras" se decepcionaram com os rumos da "República da Política" no governo de Floriano Peixoto (1891-1894), ${ }^{27}$ Eliseu passou a se valer da produção poética para descerrar os problemas, desafios e dilemas da jovem República. ${ }^{28}$ Em 1892, foi um dos fundadores do Club Cardoso Vieira, ${ }^{29}$ onde fez parte da diretoria, ocupando o cargo de orador. Já na solenidade de fundação dessa associação cívico-literária de orientação republicana, ele "conjurou aos associados para tudo empenharem no sentido de darem todo o vigor possível àquela obra do progresso e civilização" ${ }^{30}$ Cabia aos jovens a tarefa de "salvar" a República.

25 José Murilo de Carvalho, Os bestializados: o Rio de Janeiro e a República que não foi, São Paulo: Companhia das Letras, 1987, pp. 11-12.

26 Maria Tereza Chaves de Mello, A República consentida, Rio de Janeiro: FGV, 2007; Renato Lemos, "A alternativa republicana e o fim da monarquia", in Keila Grinberg e Ricardo Salles (orgs.), O Brasil Imperial, Vol. III (1870-1889) (Rio de Janeiro: Civilização Brasileira, 2009), pp. 401-444.

27 Carvalho, Os bestializados, p. 26.

28 Elizeu Cezar, "Brado à Mocidade", O Parahybano, Paraíba do Norte, 14/08/1892. Também está reproduzida em Eduardo Martins, Elyseu Elias Cezar: nota biobibliográfica, João Pessoa: Instituto Histórico e Geográfico da Paraíba, 1975, pp. 37-39.

29 Manoel Pedro Cardoso Vieira (1848-1880) era "pardo", livre, filho de proprietários de engenho e de escravizados. Formou-se pela Faculdade do Direito do Recife. Fundou o jornal satírico O Bossuet da Jacoca (1875) e escreveu sobre temas políticos para vários jornais. Lecionou "retórica" no Lyceu Paraibano, que formava a elite provincial. Foi Deputado Geral na legislatura 1878-1881 e morreu precocemente de "febre perniciosa" ainda no exercício do mandato, em 1880, com 32 anos. Sobre sua trajetória, cf. Eduardo Martins, Cardoso Vieira e o Bossuet da Jacoca: nota para um perfil biográfico, 1975; e Solange P. Rocha, "Cardoso Vieira, um homem negro na composição das elites na Paraíba oitocentista: biografia, memória e história", Revista Crítica Histórica, ano III, n. 6 (2012), pp. 1-18.

Estado do Parahyba, 05/041892. 
A palavra verbalizada e a palavra escrita constituiriam uma imbricação importante na trajetória de Eliseu, servindo, especialmente, para esse jovem negro se afirmar em meio ao processo de racialização e às incertezas da sociedade brasileira no decurso do pós-abolição e da aurora republicana. ${ }^{31}$ Em 1894, com 23 anos, publicou Algas, um livro de poesias cujo prólogo foi assinado por João Pereira de Castro Pinto, um renomado intelectual e político da Paraíba. As poesias de Eliseu, que receberam uma resenha crítica no Jornal do Recife, ${ }^{32}$ são de "extração lírica" e podem ser filiadas às "ramificações da poética romântica". Sua narrativa é calcada num "vocabulário simples e numa estratégia imagética de fácil acessibilidade". ${ }^{33}$

\section{Do Recife à Belle Époque amazônica}

Em 1895, Eliseu se transferiu para a cidade do Recife, a fim de realizar um sonho: cursar a Faculdade de Direito. A vida na capital pernambucana foi permeada, nas palavras de Humberto de Campos, "de sacrifícios e labutas cotidianas". ${ }^{34}$ Residiu na rua Barão de São Borja, numa república de estudantes; trabalhou como tipógrafo, sua primeira profissão. Posteriormente, se tornou colaborador de alguns diários, como A Província, e continuou publicando poemas. ${ }^{35}$ Nesses anos de formação jurídica, participou de

31 Wlamyra R Albuquerque, O jogo da dissimulação: abolição e cidadania negra no Brasil, São Paulo: Companhia das Letras, 2009; Ana Flávia Magalhães Pinto, Escritos de liberdade: literatos negros, racismo e cidadania no Brasil oitocentistas, Campinas, SP: Editora da Unicamp, 2018; Karl Monsma, A reprodução do racismo: fazendeiros, negros e imigrantes no oeste paulista, 1880-1914, São Carlos: EdUFSCar, 2016; Martha Abreu, Da senzala ao palco: canções escravas e racismo nas Américas, 1870-1930, Campinas: Editora Unicamp, 2017.

32 "Livros novos", Jornal do Recife, Recife, 14/10/1894, p. 2.

33 Hildeberto Barbosa Filho, "Eliseu César", in Sérgio de Castro Pinto (coord.), Coletânea de autores paraibanos (João Pessoa: Estado da Paraíba, 1987), p. 76.

34 Humberto de Campos, "Eliseu César", in Humberto de Campos, Carvalhos e roseiras: figuras políticas e literárias (Rio de Janeiro: W. M. Jackson Editores, 1947), pp. 71-81.

35 “Ante uma virgem morta”, Jornal do Recife, Recife, 11/05/1898, p. 2. 
reuniões da "mocidade acadêmica" ${ }^{36}$ aprimorou-se nas lides jornalísticas e na arte da oratória. ${ }^{37}$ Bacharelou-se em Direito em 1898. ${ }^{38}$

Ainda não sabemos a motivação de Eliseu migrar do Recife, mas provavelmente resolveu aproveitar a primeira oportunidade que lhe surgiu para fazer carreira profissional no campo jurídico. Vamos encontrá-lo um ano antes da formatura na capital do Espírito Santo, para desempenhar as atribuições de representante do Ministério Público. Ocupava o cargo de promotor público e, de reboque, militava na imprensa diária ${ }^{39}$ e palestrava celebrando a "vida da República, concitando todas as energias nacionais a libertarem-na dos males de hoje e fazê-la próspera, grande e abençoada no futuro". ${ }^{40}$ Nessa altura, já era casado com Bernardina Honorata e pai de "filhinhas". ${ }^{41}$ Ironias da história. De acordo com Santos Netto, sua passagem por Vitória (Espírito Santo) se tornou uma derrota na vida de Eliseu, pois teria chegado "a vender os últimos livros para garantir a subsistência". ${ }^{42}$ Sua experiência em Vitória não fincou raízes. Seja como for, pavimentou o caminho do Sudeste para outro Norte.

Por indicação de algum amigo, ou mesmo pelas propagandas sobre as possibilidades de se atuar no Norte do Brasil, Eliseu resolveu fazer as malas e se mudar para Belém, capital do Pará, que desde a segunda metade do século XIX ascendia economicamente, graças à extração e a comercialização do látex, matéria-prima fundamental para a produção da borracha. No apogeu da produção e exportação de borracha, ocorrido entre 1870 e 1910, Belém foi palco de um intenso processo de modernização. A cidade exibia, nesse período da chamada Belle Époque

36 "Reunião acadêmica", Jornal do Recife, Recife, 14/03/1897, p. 3.

37 "Parahyba", Diário de Pernambuco, Recife, 13/11/1897, p. 2; "Digno de ser atendido", Jornal do Recife, Recife, 13/03/1898, p. 4.

38 Henrique Martins, Lista geral dos bacharéis e doutores que têm obtido o respectivo grau na Faculdade de Direito do Recife desde sua fundação em Olinda, em 1828, até o ano de 1931, Recife: Typografia Diário da Manhã, 1931, p. 58, nos informa que "Elyzeu Elias Cezar" formou-se bacharel em "Jurídicas e Sociales".

39 "Promotor da Justiça”, Commercio do Espírito Santo, Vitória, 23/04/1897, p. 1; “D. João Nery”, O Estado do Espírito Santo, Vitória, 19/05/1897, p. 1; "Dr. Elyseu Cezar", O Estado do Espírito Santo, Vitória, 18/06/1898, p. 1; "Dr. Elyseu Cezar", A União, Parayba, 15/04/1897, p. 2.

40 “Dr. Elyseu Cezar", p. 1.

41 "Dr. Elyseu Cezar", p. 1.

42 Santos Netto, Perfis do Norte, Rio de Janeiro, Garnier, 1910, p. 94. 
amazônica, pujante vida social, sofisticados equipamentos urbanos, avançados projetos arquitetônicos e inovadores bens culturais, o que a posicionava entre as cidades brasileiras mais desenvolvidas. Mais do que ser um lugar de oportunidades, atraindo trabalhadores brasileiros e estrangeiros de diversos quadrantes, Belém tornou-se a Meca dos que desejavam vencer na vida. ${ }^{43}$

A cidade passou por profundas transformações sociais em sua paisagem urbana. A explosão demográfica do último quartel do século XIX fez sua população saltar de 61.997 para 96.560 habitantes entre $1872 \mathrm{e}$ 1890. Considerando todo o estado do Pará, esse crescimento foi ainda maior: de 275.237 a 445.356 habitantes. Em 1920, quando já havia passado o ápice do "entreposto da borracha", a população atingiu 236.402 habitantes na capital e 983.507 no estado, segundo o Instituto Brasileiro de Geografia e Estatística (IBGE).

Um dos principais responsáveis pelo processo de modernização de Belém foi Antônio Lemos, um empreendedor e notável liderança política, ligado ao Partido Republicano do Pará (PRP), que foi intendente (cargo correspondente ao de prefeito) da cidade entre 1897 e 1911. Inspirado nos padrões culturais dos principais centros europeus, implementou uma série de reformas urbanas: retirou cortiços do centro, instalou rede de esgotos, criou o serviço de transporte público, erigiu edifícios (palacetes e casarões) suntuosos, construiu praças grandes e arborizadas, inaugurou teatro, cinema e hotéis, sem contar que calçou e alargou ruas, abriu avenidas e investiu no embelezamento da cidade. Em nome

43 Franciane Lacerda aborda em seu estudo a migração de nordestinos, especialmente cearenses, para atuarem como trabalhadores nos seringais. As elites procuravam, assim, minimizar a escassez de mão de obra na extensa região do Pará e incrementar o desenvolvimento de seu principal produto de exportação, a extração de látex. Cf. Franciane G. Lacerda, "Migrantes no Pará: faces da sobrevivência (1889-1916)" (Tese de Doutorado, Universidade de São Paulo, 2006). Segundo Barbara Weinstein, as elites da região Amazônica buscaram aliciar "imigrantes europeus", oferecendo lotes de terras gratuitas ou com baixos preços. Cf. Barbara Weinstein, A borracha na Amazônia: expansão e decadência (1850-1920), São Paulo: Hucitec, 1993, p. 139. Todavia não apenas os "imigrantes europeus" se sentiram atraídos. Em pesquisa mais recente, Maria Roseane Lima desvelou os fios de uma trama apagada da memória: a imigração de trabalhadores "barbadianos" - termo utilizado como metáfora para se referir aos imigrantes negros oriundos de diversas partes do Caribe - para o Pará no contexto da "Belle Époque amazônica". Cf. Maria Roseane C. Lima, "Barbadianos negros e estrangeiros: trabalho, racismo, identidade e memória em Belém de início do século XX" (Tese de Doutorado, Universidade Federal Fluminense, 2013). 
do "novo regime" que se consolidava - a República - Lemos postulava o "ideário do progresso e da civilização". ${ }^{44}$

Sob sua administração, Belém recebeu muitos migrantes nordestinos; alguns dos quais jovens poetas, escritores, jornalistas e advogados - como Humberto de Campos, Carlos Dias Fernandes e Castro Pinto. Todos movidos pela "ilusão do eldorado". Entre esses migrantes estava Eliseu César, que lá desenvolveu a atividade advocatícia, não tardando para se destacar no tribunal do júri. ${ }^{45}$ Também trabalhou como redator da Gazeta de Belém, órgão oficial do Partido Republicano, e colaborou com A Província do Pará, um vespertino fundado em 1876 por três sócios, mas que em novembro de 1889 passou a pertencer unicamente ao político Antônio Lemos. Consta que o intendente não mediu esforços para contratar um "novo corpo de redatores", trazendo para seu periódico os jornalistas mais promissores. Em questão de tempo, A Província do Pará se tornou o "melhor jornal de todo o Norte". ${ }^{46}$

Eliseu alinhou-se a Lemos, para quem passou a trabalhar e estabelecer laços de amizade e fidelidade política. Nas páginas d'A Província do Pará, usou por um tempo o pseudônimo de Guajarino, quando escrevia sobre política, literatura e assuntos gerais. No início de 1900, temos notícia de que ele estava atuando na Secretaria da Intendência

44 Maria de Nazaré Sarges, Memórias do velho intendente: Antonio Lemos (1869-1973), Belém: Paka-Tatu, 2004.

45 "Drs. Elyseu Cezar e Alvaro Adolpho, advogados", Estado do Pará, Belém, 08/11/1911, p. 2. Outro advogado negro, que migrou do Nordeste (Recife) para o Norte, especificamente Manaus, com passagem por Belém nesse período, foi Monteiro Lopes. Depois de ter se formado em Direito e exercido atividades advocatícias em sua cidade natal, ele - na esteira do irmão, que já havia firmado residência em Belém - se transferiu em 1892 para a capital do florescente estado do Amazonas, onde permaneceu por cerca de um ano e meio, até se mudar para o Rio de Janeiro e trilhar uma ascendente carreira política. Sobre a trajetória de Monteiro Lopes, cf. Carolina Vianna Dantas, "Monteiro Lopes (1867-1910): um líder da raça negra na capital da República”, Afro-Ásia, n. 41 (2010), pp. 167-209; Petrônio Domingues, “"Vai ficar tudo preto': Monteiro Lopes e a cor na política", in Flávio dos Santos Gomes e Petrônio Domingues, Da nitidez e invisibilidade: legados do pós-emancipação no Brasil (Belo Horizonte: Fino Traço, 2013), pp. 127-156. Para dados e informações de sua temporada em Manaus, conferir Juarez Clementino da Silva, "Um negro de poder no Amazonas da Primeira República: Monteiro Lopes, o jurista e deputado (1892-1910)" (Dissertação de Mestrado, Universidade Federal do Maranhão, 2016).

46 Maria de Nazaré Sarges, Belém: riquezas produzindo a belle-époque (1870-1912), Belém: Paka-Tatu, 2002, pp. 142-143. 
de Belém, "servindo de secretário" ${ }^{47}$ Isso indica que Eliseu já estava há algum tempo no Norte, talvez um ano, e participava ativamente da administração municipal, sendo nomeado para um cargo de confiança no primeiro escalão. Em alguns momentos, ele respondia como "intendente interino". ${ }^{48}$ Cada vez mais ganhou prestígio no grupo governista de Antônio Lemos. Ainda em 1900, o diretor da Instrução Pública do estado do Pará o convidou para ministrar a primeira de uma série de conferências "cívicas". Na manhã de sete de setembro daquele ano, justamente quando se comemorava a Independência do Brasil, Eliseu ocupou o proscênio do Teatro da Paz, em Belém, e, diante da "mocidade escolástica" que cerrava fileiras na plateia, teceu um discurso laudatório da República:

No atual momento, por assim dizer ainda de consolidação política, nenhum melhor serviço se pode prestar à República. Chamar o povo às festas cívicas, chamar o coração virgem da mocidade, guiar até ao altar democrático crianças e senhoras, a representação de todas as classes sociais, todos aqueles que nasceram no regaço da nossa natureza e sentem o coração palpitando na dor e na alegria nacional, é prestigiar a República, alicerçando-a da opinião, criando-lhe na alma pública as sinceridades que não recuam mesmo ante o limite supremo do sacrifício. ${ }^{49}$

Em 1904, Eliseu tornou-se Deputado Estadual pelo PRP e liderança dessa agremiação partidária e, ao que parece, gostou da experiência de exercer mandato no âmbito do Poder Legislativo. Orador fluente, era recebido nas praças, no fórum, nas associações de estudantes ou nos círculos operários. Em 1905, ele passou a dirigir O Jornal, um novo diário vinculado ao Partido Republicano Paraense, ${ }^{50}$ que tinha como objetivo difundir o programa da "mais sólida" e da "mais patriótica" agremiação política do Brasil republicano. Tratava-se, pois, de um “jornal de combate,

47 “Dr. Santos Estanislau”, O Pará, Belém, 02/02/1900, p. 1; O Pará, Belém, 22 mar. 1900, p. 3.

48 “Animal apreendido", O Pará, Belém, 23/02/1900, p. 3; "Animal apreendido”, O Pará, Belém, 28/03/1900, p. 3.

49 Elyseu Elias Cezar, Primeira Conferência Pública realizada no Theatro da Paz na manhã do dia 7 de Setembro de 1900, Belém: Imprensa Official, 1900, p. 11. Disponível no acervo da Fundação Cultural do Pará.

50 “Interior", Gazeta de Notícias, Rio de Janeiro, 06/02/1905, p. 2. 
o panfletário que chamava a si as lutas e as polêmicas de cunho político". ${ }^{51}$ Segundo relatos de contemporâneos, Eliseu se tornou um polemista e, usando sua "pena", defendia a política lemista. ${ }^{\mathbf{2}}$

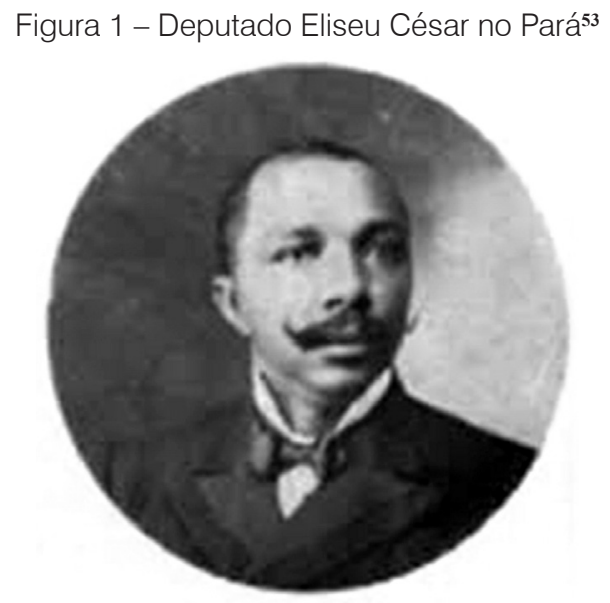

Eliseu era descrito, por quem o conheceu nessa época, como um "negro de lábios grossos", "alto", "magro", "olhos grandes", "testa ampla", "fisionomia severa, algo carrancuda". Andava "desajeitado", vestia um "fraque que se desengonçava", tinha "gestos largos", "riso franco", "alma aberta". ${ }^{54}$ Levava uma vida ditosa. Morava confortavelmente. Esbanjava poder aquisitivo, participava das articulações políticas "palacianas" e frequentava as rodas intelectuais e da "boa sociedade". Como autoridade pública, profissional bem-sucedido e "homem de letras", desfrutava de poder, renda e prestígio. Tanto que, em 1906, quando foi acometido de "cruel enfermidade", teria partido a bordo do vapor para a ilha de Barbados, no Caribe, onde mantinha residência, "a bem do repouso" que necessitava, e donde só voltou quase três meses depois, restabelecido, reassumindo mais tarde suas funções de

51 Carlos Rocque, A história da “A Provincia do Pará”, Belém: Mitograph, 1977, p. 109.

52 Santos Netto, Perfis do Norte, p. 104.

53 Augusto Montenegro (org.), Álbum do Estado do Pará (1901-1909), Paris: Chaponet, 1908, p. 27.

54 “Elyseu Cesar", Diário de São Luiz, Maranhão, 09/02/1923, p. 1. 
redator-chefe d'O Jornal. ${ }^{55}$ Sobre ele, dizia a Revista Azul, de Lisboa: "Jornalista primoroso e advogado distinto, o dr. Elyseu Cezar é uma das glórias do Brasil moderno, de que ele se ufana e com razão". ${ }^{56}$

Parece ter sido em Belém que Eliseu César amadureceu como intelectual afro-diaspórico, cujas práticas culturais e ações políticas no sentido de agenciar conhecimentos e comunicar ideias estavam, direta ou indiretamente, ligadas à produção de mensagens, bens culturais e intervenção político-social. ${ }^{57}$ Em 1912, Antônio Lemos foi destituído do poder por seus adversários, os seguidores do então governador Lauro Sodré. Enxovalhado em praça pública, partiu para autoexílio no Rio de Janeiro. Seguiu os passos de Eliseu, seu assecla que, ao prever o final do domínio do proeminente morubixaba de Belém, resolveu pedir demissão do cargo de Secretário ${ }^{58}$ e migrar antes para a capital da República. Mais um deslocamento em sua vida. De forma açodada, seguiu em busca de novos anseios, horizontes de expectativas, possibilidades, enfim, de um novo recomeço.

\section{Na capital da República}

Eliseu César viajou para o Rio de Janeiro no final de $1911 .{ }^{59}$ Ao chegar ao local de destino no início do ano novo, encontrou uma cidade de aura cosmopolita, que, após a reforma urbana na gestão do prefeito Pereira Passos em 1904, era vista como uma capital à altura dos principais

55 A respeito da estada de Eliseu César em Bridgetown, capital de Barbados, ver o relato de um funcionário diplomático, que ali o conheceu por intermédio do cônsul brasileiro do país caribenho. "Elyseu Cesar", O Imparcial, Rio de Janeiro, 17/01/1921, p. 6; Martins, Elyseu Elias Cezar, pp. 21-22.

56 Revista Azul, Lisboa, abr. 1907.

57 Na concepção de Angela de Castro Gomes e Patrícia Hansen, intelectuais são "homens da produção de conhecimentos e comunicação de ideias, direta ou indiretamente vinculados à intervenção político-social. Sendo assim, tais sujeitos podem e devem ser tratados como atores estratégicos nas áreas da cultura e da política que se entrelaçam, não sem tensões, mas com distinções, ainda que historicamente ocupem posição de reconhecimento variável na vida social”. Cf. Angela de Castro Gomes e Patrícia Santos Hansen, "Apresentação", in Angela de Castro Gomes e Patrícia Santos Hansen (orgs.), Intelectuais mediadores: práticas culturais e ação política (Rio de Janeiro: Civilização Brasileira, 2016), p. 10.

58 Estado do Pará, Belém, 06/12/1911, p. 1.

59 “Ceará”, O Paiz, Rio de Janeiro, 24/12/1911, p. 4. 
centros urbanos da época. Epicentro da vida política nacional, o Rio de Janeiro reunia o que havia de mais saliente no setor industrial, comercial, financeiro e na rede de serviços e lazer, sem contar que abrigava uma efervescente vida social e cultural, ditando comportamentos e tendências estéticas. Símbolo de progresso e civilização, tudo ali era tido como virtualmente moderno. A cidade se converteu no cartão postal do Brasil, atraindo, desde o último quartel do século XIX, um fluxo contínuo de imigrantes europeus - em sua maioria oriundos das regiões mais pobres da Espanha, Itália e, principalmente, de Portugal - e migrantes provenientes do interior e de outros estados, sobretudo do "Norte". Sua população, nesse período, cresceu em ritmo acelerado. De 522.651 habi-

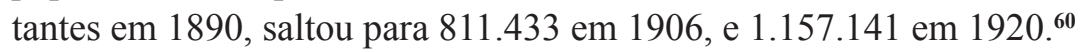

Os novos habitantes, em sua maior parte, viam no Rio de Janeiro um oásis de oportunidades, com direito a emprego, moradia, mobilidade social, ascensão cultural e melhores condições de vida. Porém logo percebiam que ali nem tudo fazia lembrar a terra de promissão. A cidade concentrava uma série de problemas relacionados à educação, habitação, saúde pública, mobilidade urbana, carestia, ao abastecimento de água e saneamento básico, o que acarretava a degradação na qualidade de vida. Muitas pessoas viviam modicamente, quando não em estado de vulnerabilidade, nos cortiços da região central, nos morros, subúrbios e arrabaldes. Eram desempregados (ou subempregados), operários das oficinas e fábricas, estivadores, ambulantes, biscateiros, criados, malandros, prestadores de serviços manuais, funcionários precarizados do comércio, serventes de repartições públicas, entre outros subalternos da estrutura ocupacional. ${ }^{61}$

60 Jeffrey Needell, Belle Époque tropical: sociedade e cultura de elite no Rio de Janeiro na virada do século, São Paulo: Companhia das Letras, 1993; Teresa A. Meade, "Civilizing” Rio: reform and resistance in a Brazilian City, 1889-1930, Philadelphia: Pennsylvania State University Press, 1997; Nicolau Sevcenko, "A capital irradiante: técnica, ritmos e ritos do Rio", in Nicolau Sevcenko (org.), História da vida privada no Brasil: República - v. 3 (São Paulo: Companhia das Letras, 1998).

61 Adolfo Morales de los Rios Filho, "O Rio de Janeiro da Primeira República (1889-1930)", Revista do Instituto Histórico e Geográfico Brasileiro, v. 272 (1966), pp. 3-158; June Hahner, Pobreza e politica: os pobres urbanos no Brasil (1870-1930), Brasília: Editora UnB, 1993; João do Rio (Paulo Barreto), A alma encantadora das ruas: crônicas, São Paulo: Companhia das Letras, 2008. 
Quando se estabeleceu no Rio de Janeiro, ${ }^{62}$ Eliseu César decidiu morar em São Cristóvão, um bairro suburbano da atual zona norte. Seu primeiro emprego foi como redator do Jornal do Brasil, um matutino fundado em 1891 que se arvorou na urbe como caixa de ressonância da "voz do povo". Valendo-se ao longo dos anos de colaboradores de prestígio, como Joaquim Nabuco, Rui Barbosa e José Veríssimo, o jornal se vangloriava de ser, em 1900, o de maior tiragem da América do Sul e de possuir, em 1916, o maior parque gráfico da imprensa brasileira. ${ }^{63} \mathrm{~A}$ transferência de Eliseu César para a capital da República marcou o início de uma nova fase em sua trajetória. Se na época da hegemonia política de Antônio Lemos em Belém ele levava uma vida confortável, ostentando renda, poder e status, esse quadro faria parte do passado. A destituição daquele chefe político implicou a bancarrota de seu fiel escudeiro, que passou a ser visado pelos novos donos do poder. Daí o "refúgio" no Rio de Janeiro, onde só não passou necessidades devido à sua disposição de trabalho. No Jornal do Brasil, Eliseu se dedicava à produção de conteúdo informativo, redigindo matérias, revisando editoriais, burilando crônicas, porém sua remuneração jamais permitiu usufruir de uma vida estável, razão pela qual ele procurou outros meios para melhorar seu padrão de renda. Paralelamente, labutou como redator dos jornais $A$ Razão,${ }^{64}$ Sete Horas $^{65}$ e colaborou com as revistas Carioca, Comércio Americano e A Faladora. ${ }^{66}$

Diante das incertezas e privações da vida modesta ligada às lides jornalísticas no Rio de Janeiro, Eliseu resolveu aceitar o convite de Nascimento Júnior para exercer o cargo de redator-chefe d'A Tribuna, o mais importante jornal de Santos. Mudou-se para a cidade do litoral

"Várias notícias", Jornal do Commercio, Rio de Janeiro, 21/02/1912, p. 4; "De Recife para o Rio”, Correio da Manhã, Rio de Janeiro, 18/02/1918, p. 5.

63 Antonio Herculano Lopes, "Do monarquismo ao 'populismo': o Jornal do Brasil na virada do século XX”, in Lúcia Maria das Neves, Marco Morel e Tânia Bessone Ferreira (orgs.), História da imprensa: representações culturais e práticas de poder (Rio de Janeiro: DP\&A, 2006), pp. 332-345.

64 “A Razão”, A Noite, Rio de Janeiro, 02/11/1916, p. 4.

65 “7 horas", Correio da Manhã, Rio de Janeiro, 10/11/1914, p. 3; O Imparcial, Rio de Janeiro, 10/11/1914, p. 7.

66 “A Faladora”, Correio da Manhã, Rio de Janeiro, 11/11/1915, p. 3. 
paulista. ${ }^{67}$ Sua passagem por lá, entretanto, foi efêmera. ${ }^{68}$ Regressou à capital federal, onde voltou a militar na imprensa. As necessidades da família dissuadiram-no de não continuar tão somente "perdendo tempo naqueles trabalhos, sem remuneração vantajosa, nem futuro. Assim, a vida do fórum seduziu-o pela segunda vez" e ele passou a atuar também como advogado. ${ }^{69}$ Para tanto, abriu um escritório de advocacia na rua dos Andradas, $\mathrm{n}^{0} 101$, no centro do Rio de Janeiro, ${ }^{70}$ posteriormente mudou o escritório para Avenida Passos, $n^{\circ}$ 61, sobrado, também no coração da cidade, onde era encontrado "de $10 \mathrm{~h} 00$ às $12 \mathrm{~h} 00$ da manhã e de $15 \mathrm{~h} 00$ às $18 \mathrm{~h} 00$ da tarde". ${ }^{71}$

Especializando-se no Direito Penal, Eliseu César participou de vários julgamentos no Tribunal do Júri e assumiu alguns casos de repercussão, como o de Alexandrina Nunes da Silva, que foi acusada de ter assassinado o seu ex-amante, Belisário Joaquim Rodrigues; ${ }^{72} \mathrm{o}$ do general Figueiredo Rocha, que foi pronunciado ao Conselho de Justiça pelo ministro da Guerra, Pandiá Calógeras, por ter supostamente incorrido em crime de transgressão, ${ }^{73}$ e o caso que ficou conhecido como o "crime da Rua da Lapa". No dia 13 de janeiro de 1920, o tenente Arthur Guedes de Abreu assassinou sua esposa, Iracema Guedes de Abreu, fato ocorrido no sobrado da rua da Lapa, $\mathrm{n}^{\circ} 19$, onde residia a vítima, que estava separada judicialmente de seu marido. $\mathrm{O}$ crime abalou a opinião pública, dadas as circunstâncias. ${ }^{74}$ Naquele dia, o tenente Abreu, pretextando fazer as pazes com a esposa, foi ao seu encontro e, quando a sós

"Passageiros entrados. Santos", Correio Paulistano, São Paulo, 11/02/1914, p. 7.

68 Eis o que o Correio Paulistano noticiou: "Santos, 5 - Deixou hoje a redação da "Tribuna" o sr. Eliseu César. Informam-nos que este jornalista assim procedeu por não ser solidário com a atual orientação política daquela folha". Correio Paulistano, São Paulo, 06/06/1914, p. 4. Cf. também "Dr. Elyseu Cesar", A Gazeta, São Paulo, 05/06/1914, p. 8.

69 “O falecimento do Dr. Elyseu Cesar", Gazeta de Notícias, Rio de Janeiro, 03/02/1923, p. 4.

70 A Época, Rio de Janeiro, 20/05/1916, p. 5.

71 "Advogado", Correio da Manhã, Rio de Janeiro, 06/07/1921, p. 5.

72 "Tribunal do juri. Julgamento de uma mulher", O Paiz, Rio de Janeiro, 10/08/1922, p. 5; “A vindicta", Gazeta de Notícias, Rio de Janeiro, 10/08/1922, p. 5.

73 "O caso do general Figueiredo Rocha", Gazeta de Notícias, Rio de Janeiro, 29/03/1921, p. 1; "O general Figueiredo Rocha foi impronunciado", O Paiz, Rio de Janeiro, 31/03/1921, p. 4; "O Conselho de Justiça impronunciou o general Figueiredo Rocha", Gazeta de Notícias, Rio de Janeiro, 31/03/1921, p. 3.

74 “O crime da rua Lapa", O Paiz, Rio de Janeiro, 15/01/1920, p. 5. 
com ela, na sala da frente do prédio, assassinou-a cruelmente, com vários tiros desferidos à queima roupa. Preso e conduzido à polícia, confessou o crime prestando, no auto de flagrante, minucioso depoimento, reconstituindo toda a vida do casal até o momento do assassinato. Alegou que, diante da negativa da esposa de reatar o casamento, ficou alucinado, perdeu a cabeça e não sabia o que havia feito. ${ }^{75} \mathrm{O}$ tenente Abreu foi parar no banco dos réus e, para defendê-lo, contratou dois advogados: Evaristo de Moraes e Eliseu César.

\section{Figura 2 - Os advogados Eliseu César e Evaristo de Moraes} no julgamento do tenente Abreu

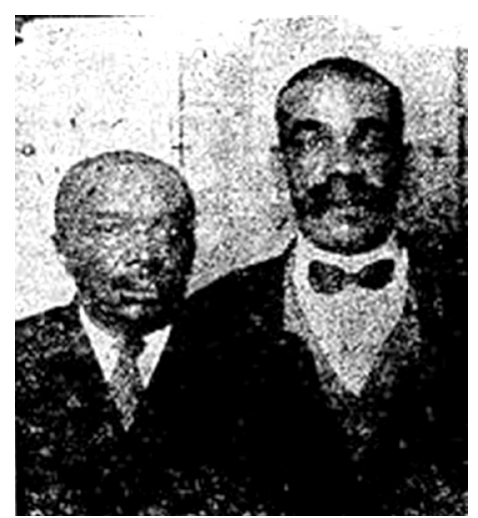

Fonte: Gazeta de Notícias. ${ }^{76}$

Evaristo de Moraes era um "mulato" nascido no Rio de Janeiro em 1871. Cedo, posicionou-se no debate público, participando dos movimentos abolicionista e republicano. Escreveu para a imprensa sobre diversos temas sociais, publicou vários livros, enfronhou-se no movimento sindical e articulou a construção de partidos socialistas. Não obstante, sua maior vocação era a advocacia. Estreou no Tribunal do Júri como rábula e não mais parou, tornando-se um dos principais especialistas em Direito Penal nas primeiras décadas do século XX, com atuações primorosas na defesa de acusados. Portava-se nas barras dos tribunais, muitas vezes,

75 "O crime do tenente", Jornal do Brasil, Rio de Janeiro, 16/07/1920, p. 9; "O Jury de ontem", Jornal do Brasil, Rio de Janeiro, 17/07/1920, p. 7.

76 Gazeta de Notícias, Rio de Janeiro, 17/07/1920, p. 2. 
como um ator em cena. Sua oratória - que combinava gesticulações e pronúncia das palavras - buscava conquistar os jurados pela emoção e convencer os doutos pela erudição. ${ }^{77}$

Eliseu César também se notabilizou pela capacidade de, a favor de seus constituintes, mobilizar a emoção no tribunal. Simões Dias, um jornalista português, conta que um dia foi assistir a um julgamento célebre em Belém. A causa era sensacional. $O$ tribunal estava repleto. Quando o juiz deu a palavra ao advogado de defesa, eis que Eliseu César, um "negro alto espadaúdo", levantou-se a "toda altura". Comoveu os ouvintes, dando "voos de eloquência". "Vibrei de emoção. Empolgara-me. E desde então ficamos amigos. Admirei o seu talento desde essa hora" ${ }^{78}$ Conquanto essa história relatada por Simões Dias pudesse ser exagerada ou mesmo fantasiosa, não deixa de indicar que havia um traço marcante na atuação daquele advogado, que chegou a ser considerado o "[Joaquim] Nabuco negro na eloquência". ${ }^{79}$

De volta ao "crime da Rua da Lapa". Eliseu assumiu a causa do tenente Abreu depois de ter recebido uma carta assinada por "cento e tantos oficiais do exército", pedindo-lhe que aceitasse o "patrocínio da causa". ${ }^{80}$ Aguardado com expectativas, o julgamento do tenente teve início no dia 12 de julho de 1920. Desde cedo o Tribunal do Júri mantinha o aspecto habitual das ocasiões de julgamentos de processos importantes. Verificou-se grande concorrência de advogados, jornalistas e curiosos, destacando-se algumas senhoras. $\mathrm{O}$ ingresso na sala das sessões era feito mediante cartões fornecidos pelo juiz às pessoas. Após a abertura do julgamento e a leitura do processo realizada pelo escrivão, o juiz presidente do Tribunal, Álvaro Bittencourt Belford, franqueou a palavra ao promotor público, André de Faria Pereira, para fazer a acusação. O representante do Ministério Público consignou que D. Iracema era vítima dos maus tratos de seu marido, passando, além disso, uma vida de necessidades

77 Joseli Maria N. Mendonça, Evaristo de Moraes, tribuno da República, Campinas: Editora Unicamp, 2007, p. 208.

78 “De janela aberta...”, A Gazeta, São Paulo, 28/01/1924, p. 1.

79 Rodrigues de Carvalho, "Aspectos da influência africana na formação social do Brasil", Novos Estudos Afro-Brasileiros: Trabalhos apresentados no I Congresso Afro-Brasileiro (Recife, 1934), Recife: Fundação Joaquim Nabuco; Massangana, 1988. Edição Fac-similar, v. 2, pp. 15-74.

“A vida e a morte de D. Iracema de Abreu”, Gazeta de Notícias, Rio de Janeiro, 16/07/1920, p. 1. 
e privações. Argumentou que os autos reuniam uma série de elementos de prova no sentido de atestar a culpa do réu, com todos os agravantes de um crime hediondo e premeditado. Findada a acusação, o juiz paralisou os trabalhos a fim de dar descanso aos jurados. Reiniciado o julgamento noutro dia, usou da palavra em primeiro lugar o advogado do réu, Eliseu César, e, a seguir, Evaristo de Moraes. ${ }^{81}$ Durante duas horas, Eliseu produziu uma "belíssima peça oratória, empolgando o auditório. Analisando o processo, conseguiu dele tirar elementos para provar ser o acusado um criminoso passional". Incontinenti foi dada a palavra ao outro advogado do acusado. Evaristo de Moraes desenvolveu longas considerações tendentes a "demonstrar ser o criminoso um irresponsável, ter agido em desafronta da sua honra ultrajada pela vítima". Afora isso, refutou a acusação produzida contra seu "constituinte e terminou pleiteando a absolvição do tenente Abreu pela dirimente da privação dos sentidos e da inteligência no ato de praticar o crime". O Conselho de Sentença, depois de conferenciar na sala secreta, voltou ao recinto do Tribunal, votando a absolvição do réu por quatro votos. ${ }^{82}$

\section{$* * *$}

No Rio de Janeiro da Primeira República, ganhou cada vez mais espaço a defesa da esfera pública, a luta pela participação social e cultural mais ampla, o desejo pela ampliação da vida política e os combates pela carreira aberta ao talento. Os diversos segmentos da sociedade perceberam que as novas formas de associativismo "seriam muito importantes tanto para suas demandas mais gerais quanto para o fortalecimento de suas estratégias de proteção e de organização". ${ }^{83}$ Aliás, os estudiosos

81 "O Jury de ontem", Jornal do Brasil, Rio de Janeiro, 17/07/1920, p. 7; “A morte de D. Iracema”, Gazeta de Notícias, Rio de Janeiro, 17/07/1920, p. 2; "O júri do tenente Abreu. Os debates entre a acusação e a defesa", A Noite, Rio de Janeiro, 17/07/1920, p. 4.

82 "O crime do tenente”, Jornal do Brasil, Rio de Janeiro, 18/07/1920, p. 7; “A Justiça de luto. Foi absolvido o sinistro matador da inditosa Iracema”, A Razão, Rio de Janeiro, 18/07/1920, p. 4.

83 Claudio H. M. Batalha e Marcelo Mac Cord, "Experiências associativas e mutualistas no Brasil", in Claudio H. M. Batalha e Marcelo Mac Cord (orgs.), Organizar e proteger: trabalhadores, associações e mutualismo no Brasil (séculos XIX e XX) (Campinas: Editora Unicamp, 2014), pp. 11-24. 
consideram a tendência à associação como um fenômeno marcante do período ${ }^{84}$ Associações dos mais diversos perfis foram criadas para reunir inteligências, virtudes e vontades. Além da faina do fórum e das redações dos jornais, Eliseu César participou de várias associações e frequentou alguns estabelecimentos, engajando-se em suas atividades. Ao que parece, a Associação Brasileira de Imprensa (ABI) foi uma das primeiras instituições à qual se vinculou quando chegou ao Rio de Janeiro. Nela, costumava discursar nos eventos especiais. Na sessão solene de posse da nova diretoria da ABI em 1919, por exemplo, ele fez uso da palavra, abordando as "várias fases da imprensa, sua função social e política, no passado e no presente, na paz e na guerra. Discorreu sobre a imprensa em geral como fator máximo do progresso moral e social, como a força suprema, força gloriosa e renovadora". ${ }^{85}$

Eliseu César se afiliou ao Centro Suburbano Popular, onde ocupava o cargo de orador, ${ }^{86}$ participava de eventos no Centro Operário do Rio de Janeiro, ocasiões nas quais não desperdiçava a oportunidade para discursar. ${ }^{87}$ Apoiou clubes desportivos e agremiações beneficentes ${ }^{88}$, prestou serviço de assistência jurídica a sindicato ${ }^{89}$ Tornou-se membro ativo do Centro Republicano Popular, entidade na qual desempenhava o papel de orador; ${ }^{90}$ assinou o Manifesto do Partido Republicano Nacional, intitulado "Brasil brasileiro, dos brasileiros e para os brasileiros". ${ }^{91}$ Mais tarde, cerrou fileiras no Centro Cívico 15 de Novembro, uma associação republicana onde também se destacou como tribuno. ${ }^{92}$

84 Michael L. Conniff, “'Voluntary associations' in Rio, 1870-1945: a new approach to urban social dynamics", Journal of Interamerican Studies and World Affairs, v. 17, n. 1 (1975), pp. 64-81; Vítor Manoel Marques da Fonseca, No gozo dos direitos civis: associativismo no Rio de Janeiro (1903-1916), Rio de Janeiro: Muiraquitã, 2008.

“A solenidade na Associação Brasileira de Imprensa", A Época, Rio de Janeiro, 14/05/1919, p. 8.

86 "Manifestação ao deputado Irineu Machado", O Imparcial, Rio de Janeiro, 27/02/1916, p. 4.

87 "O regresso do Sr. Epitácio Pessoa”, O Imparcial, Rio de Janeiro, 23/07/1919, p. 3.

88 "Os músicos agremiam-se", A Noite, Rio de Janeiro, 7/01/1921, p. 6.

89 "Os operários do Llyod pedem a bonificação extraordinária aos domingos", Correio da Manhã, Rio de Janeiro, 20/02/1921, p. 3.

90 “Senador Paulo de Frontin", Jornal do Commercio, Rio de Janeiro, 03/07/1917, p. 3.

91 "Brasil brasileiro, dos brasileiros e para os brasileiros", $A B C$, Rio de Janeiro, 12/04/1919, pp. 17-19.

92 "Instala-se o Centro Cívico Quinze de Novembro", Correio da Manhã, Rio de Janeiro, 16/11/1920, p. 4; "A fundação do grande Centro Republicano 15 de Novembro", Jornal do 
Ao Centro Cívico 15 de Novembro, Eliseu dedicou atenção, tempo e energia. Participava das atividades sociais e ações coletivas. Assumiu posição diretiva, presidindo eventualmente as assembleias dos associados ou mesmo fazendo o que mais o distinguia: discursar nos eventos públicos. ${ }^{93}$ Aliás, foi como orador - cujo verbo teria a "vibração encantadora dos privilegiados da palavra falada" ${ }^{94}$ - que Eliseu se destacou no movimento associativo. Quando chegou ao Rio de Janeiro e começou a participar da vida pública, discursando em meetings, sessões cívicas e "manifestações sociais", ${ }^{95}$ sua fama de tribuno popular veio à tona e aos poucos se espraiou pelos cantos e recantos da cidade. Não por acaso, o vespertino $O$ Paiz o qualificou como o "sucessor autêntico e racial de [José do] Patrocínio", ${ }^{96}$ e o padre Olympio de Castro o classificou como o "Rui Barbosa negro". 97

Martins Alonso, que por quase quarenta anos foi secretário de redação do Jornal do Brasil, registra em livro de memórias que Eliseu era "um tribuno de tal dimensão que não escolhia temas, nem a sua oratória dependia de preparação". Numa tarde, na redação do Jornal do Brasil, teria sido procurado por uma comissão de "grande e prestigiosa

Brasil, Rio de Janeiro, 16/11/1920, p. 5. O Centro Cívico 15 de Novembro foi fundado no coração do Rio de Janeiro, numa "sessão cívica" movimentada que ocorreu no salão de conferências da Biblioteca Nacional, na tarde de 15 de novembro de 1920. Iniciados os trabalhos, o presidente da sessão proferiu um discurso referente à "grande data histórica" da Proclamação da República e leu o programa formulado para reger a vida da nova entidade, cujos pontos principais eram: "Pugnar pela nacionalização do comércio a varejo, auxiliar os poderes públicos e as empresas particulares no combate ao analfabetismo; promover a criação de escolas profissionais; [...] congraçar os operários, os funcionários públicos e agricultores, na comunhão dos princípios associativos, combatendo a exploração dos políticos profissionais; prestigiar a autoridade que mereça apoio e denunciar a que, à sombra da lei, procure locupletar-se; auxiliar a organização de nosso aparelhamento econômico; restringir, mediante regulamentação legal, a drenagem, para o estrangeiro, de fabulosos lucros aqui adquiridos; [...] realizar nos Estados conferências contra os brasileiros que se aliarem a estrangeiros para negócios contrários aos interesses nacionais; pugnar pela promulgação de leis que obriguem as casas estrangeiras a incluir, entre os empregados, $50 \%$ de brasileiros". "Instala-se o Centro Cívico Quinze de Novembro", Correio da Manhã, Rio de Janeiro, 16/11/1920, p. 4; "A fundação do grande Centro Republicano 15 de Novembro", Jornal do Brasil, Rio de Janeiro, 16/11/1920, p. 5.

93 "Cousas da política", Jornal do Brasil, Rio de Janeiro, 30/011921, p. 4.

94 "Notas e notícias", Gazeta de Notícias, Rio de Janeiro, 17/10/1922, p. 1.

95 "Manifestações”, O Paiz, Rio de Janeiro, 26/08/1921, p. 5.

96 “Autores e livros", p. 1.

97 “10 Manifesto", p. 4. 
instituição cultural". Dali a pouco, em não mais de duas horas, devia ser recepcionado Rui Barbosa em sessão solene. O orador, dias antes convidado para saudá-lo, professor Pinto da Rocha, "expoente das letras jurídicas e afamado entre os oradores brasileiros", teria adoecido subitamente. Adiar a solenidade, naquela altura, estava fora de cogitação. Sugeriram então à diretoria da sociedade que procurasse Eliseu César. Este ponderou que teria de ir à sua residência distante do centro para vestir o traje adequado para o cerimonial. Todos os obstáculos foram removidos. Levaram-no de automóvel; ele "vestiu smoking, tomou rápido alimento e, na hora prevista no programa, tendo indagado apenas o sentido da homenagem, apresentou-se na tribuna e pronunciou uma oração emocionante. Rui levantou-se e correu a abraçá-1o". ${ }^{98}$

Figura 3 - Caricatura de Eliseu César na imprensa carioca

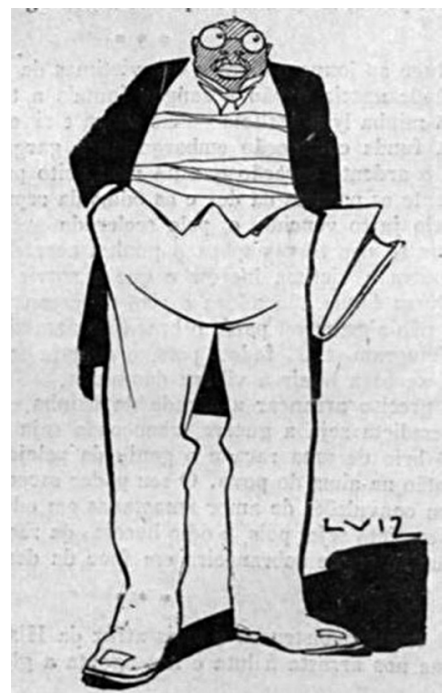

Fonte: O Malho. ${ }^{99}$

No que concerne ao associativismo, Eliseu ainda era membro ativo da Federação dos Homens de Cor (FHC) - uma sociedade beneficente

98 Martins Alonso, Ao longo do caminho: memórias, Rio de Janeiro: José Olympio, 1976, pp. 77-78.

99 O Malho, Rio de Janeiro, 09/03/1918, p. 23. 
cuja finalidade precípua era trabalhar pelo desenvolvimento moral, cultural, político e social dos afro-brasileiros -, fundada em São Paulo, em 1909, mas que se transferiu para o Rio de Janeiro uma década mais tarde. ${ }^{100} \mathrm{~A}$ FHC foi, em certa medida, uma resposta às práticas do "preconceito de cor" que afligiam a população negra cotidianamente sob a forma de barreiras, relações hierárquicas e estigmas no espaço público: na sátira jornalística, nas suspeições policiais, no acesso à justiça, a postos de trabalho, escolas, clubes, hotéis, bares e restaurantes. ${ }^{101}$ Eliseu foi alvo dessas manifestações de "preconceito de cor" em vários momentos. Contava-se que, ao ingressar na Faculdade de Direito, "fora motivo de chacota e trotes impiedosos porque era negro". ${ }^{102}$ Guimarães Barreto relata que ele foi recebido pelo "povo" do Recife, na primeira vez em que falou em evento público, com demonstrações hostis ("macaco falante", “imagem de pixe", "cala a boca, negro!"). ${ }^{103}$ Quando morava em Belém, o poeta José Augusto da Gama e Costa, considerado o "Bocage paraense", utilizou do recurso cômico para espinafrá-lo por meio de verso rimado:

Com César não te pareces,

Tão pouco com Eliseu!*

- És de certo algum macaco

Fugido lá... do museu! ${ }^{104}$

100 Petrônio Domingues, "Esta 'magnânima volição': a Federação dos Homens de Cor”, História, v. 37 (2018), pp. 1-29.

101 Álvaro Bomilcar, O preconceito de raça no Brasil, Rio de Janeiro: Tipografia Aurora, 1916; Carlos Antonio Costa Ribeiro, Cor e criminalidade: estudo e análise da justiça no Rio de Janeiro (1900-1930), Rio de Janeiro: Editora UFRJ, 1995; Jerry Dávila, Diploma da brancura: política social e racial no Brasil (1917-1945), São Paulo: Editora Unesp, 2006; Silvia Capanema Almeida e Rogério Sousa Silva, "Do (in)visível ao risível: o negro e a 'raça nacional' na criação caricatural da Primeira República”, Estudos Históricos, v. 26, n. 52 (2013), pp. 316345; Maria Margarete dos Santos Benedicto, "Quaquaraquaquá quem riu? A representação humorística sobre os negros e a questão do branqueamento: da Belle Époque aos anos 1920 no Rio de Janeiro" (Tese de Doutorado, Universidade de São Paulo, 2019).

102 Alonso, Ao longo do caminho, p. 76.

103 Guimarães Barreto, Excursão pelo reino das trovas, Rio de Janeiro: Irmãos Pongetti, 1962, p. 100.

104 “O Bocage paraense”, Ilustração Brasileira, Rio de Janeiro, dez. 1942, p. 10. * O palácio presidencial francês. 
No Rio de Janeiro, Eliseu César continuou sendo atacado de maneira preconceituosa - às vezes explícita, às vezes tácita e ironicamente -, pelo viés do escárnio. Em 1918, a revista ilustrada e humorística O Malho fez troça de sua condição de "negro alto espadaúdo", associando-o ao símio no aumentativo:

O elegante tribuno e conhecido advogado Dr. Eliseu César tem pronto o seu drama intitulado Preto no Branco, cuja primeira leitura feita a vários amigos no Café Belas Artes agradou imensamente. Eliseu César, cuja alegria radiante prevê o sucesso da vitória teatral, pediu ao beletrista Xavier Pinheiro para ser o intérprete do papel de Macacão, principal personagem do drama vivido em dezoito partes, em prólogo e um epílogo. ${ }^{105}$

A coleção de dissabores relacionada à condição racial não deixou Eliseu melindrado ou com sentimento de impotência. Pelo contrário, isso provavelmente o motivou a aderir à FHC, associação para a qual colaborou com o trabalho de valorização da população negra, ministrando palestras, prestando assistência jurídica e mesmo assumindo o posto de orador oficial. Em 1923, O Paiz acusou Irineu Machado (então senador da República pelo Distrito Federal) de ser, "invariavelmente, um negador do elemento negro, um sistemático adversário dos nossos homens de cor", a tal ponto que teria dito na Casa Legislativa: "Isto aqui não é senzala, nem lugar para negros". Em sessão da FHC, a polêmica declaração de Irineu Machado foi pautada, ocasião na qual Eliseu César teria proferido um "desabafo violento", traçando a "pontas de fogo o perfil" do senador. Com uma "oratória flamejante e indignada", o tribuno "preto" interpretou os sentimentos dos "homens de cor" e deu ao "ofensor gratuito uma inesquecível lição de ética social". ${ }^{106}$

Como se percebe, Eliseu transitava no meio associativista, articulando de maneira interseccional um ativismo social, político e cívico, que desfraldava a bandeira do republicanismo popular alicerçado numa plataforma nacionalista, a bandeira dos direitos e da igualdade de todos os indivíduos

105 "Vida elegante", O Malho, Rio de Janeiro, 09/03/1918, p. 23. Para outras pilhérias que giravam em torno da cor de Eliseu César, cf. "Eleições", O Malho, Rio de Janeiro, 05/03/1921, p. 13; O Malho, Rio de Janeiro, 23/04/1921, p. 26; A Maçã, Rio de Janeiro, 07/09/1922, p. 26.

106 "Política do Districto", O Paiz, Rio de Janeiro, 26/12/1923, p. 4. 
perante a lei, como ainda defendia a inserção do negro à comunidade nacional. Com o tempo, ele conseguiu conquistar prestígio e reconhecimento público na capital federal, com o seu nome e os dos entes familiares inclusive sendo veiculados nas colunas sociais dos jornais. ${ }^{107} \mathrm{O}$ auge desse reconhecimento se deu no governo do presidente Epitácio Pessoa (19191922) - seu conterrâneo e com quem mantinha amizade -, quando passou a frequentar gabinetes de ministros ${ }^{108}$ e até a ser recebido em audiência pela mais importante autoridade da República, conforme noticiou o Correio da Manhã: "O Sr. Presidente da República [Epitácio Pessoa] recebeu ontem em audiência os Srs. Marechal Souza Aguiar, general Ferreira Ramos, Dr. Ildefonso Marinho, Dr. Eliseu César, Dr. Alencar Lima, Oliveira e Silva, Francisco Lafayette, Lourenço de Sá Filho e Dr. Mello Rezende”. ${ }^{109}$

Figura 4 - Charge de Eliseu César na imprensa carioca

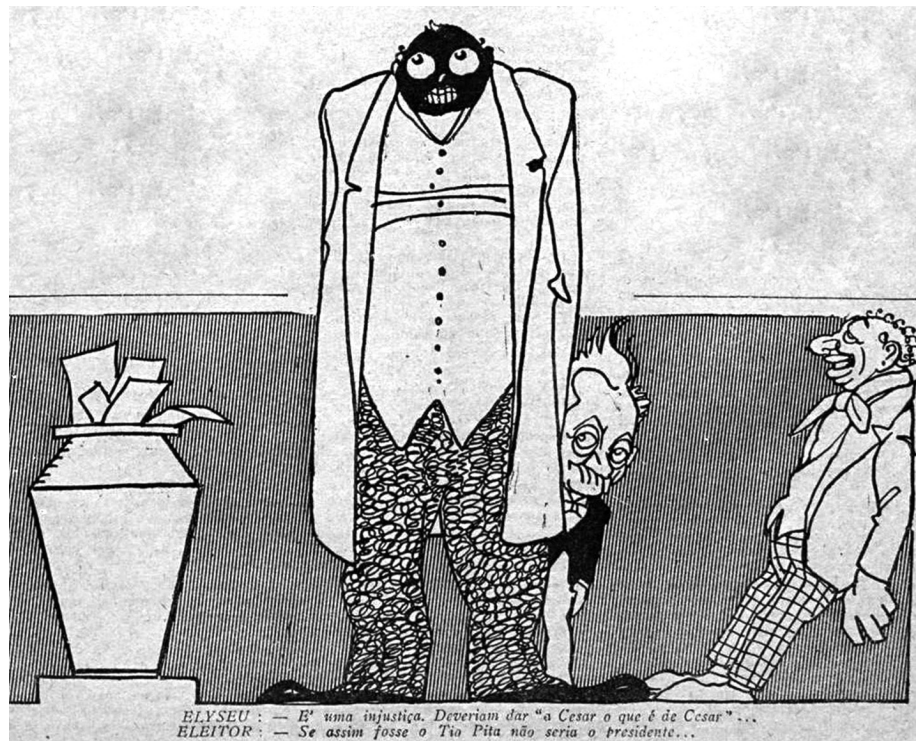

Fonte: O Malho. ${ }^{110}$

107 "Notas sociais", Jornal do Brasil, Rio de Janeiro, 01/08/1921, p. 6; "Notas sociais", Correio da Manhã, Rio de Janeiro, 07/08/1921, p. 5; "Notas sociais", Jornal do Brasil, Rio de Janeiro, 02/06/1922, p. 21.

108 "Ministério da Fazenda", O Paiz, Rio de Janeiro, 25/09/1921, p. 4.

109 Correio da Manhã, Rio de Janeiro, 06/11/1921, p. 2; O Paiz, Rio de Janeiro, 06/11/1921, p. 3.

110 O Malho, Rio de Janeiro, 05/03/1921, p. 13. 
No segundo semestre de 1920, os partidos políticos realizaram convenções para definir as candidaturas à Câmara e ao Senado, que disputariam as eleições de 20 de fevereiro de 1921. Eliseu não perdeu o bonde da história. Aproveitando o capital político e simbólico amealhado na vida pública, organizou sua candidatura a deputado federal pelo então Distrito Federal, sem, contudo, vincular-se a alguma agremiação partidária. É que a legislação eleitoral da época permitia o uso desse expediente com vistas a garantir o direito de representação das minorias. ${ }^{111}$ "Um candidato avulso", reportou o Jornal do Brasil, "o Dr. Eliseu César, vai dia a dia granjeando novas e consideráveis simpatias". ${ }^{112}$ "Assume grandes proporções a candidatura do sr. Eliseu César", assinalou O Combate. ${ }^{113}$ Tendo em vista a repercussão na imprensa, pode-se afirmar que sua candidatura foi crescendo paulatinamente em termos de agenciamento, propaganda e cooptação de novos aderentes.

Em 30 de janeiro de 1921, O Imparcial publicou uma carta de apoio de Lopes Trovão - uma histórica liderança do republicanismo popular114 - ao "ardoroso correligionário e bom amigo Eliseu César": "Estou abertamente convosco", que "sois provadamente republicano", fazendo "votos, do retiro em que me sepultei, pela vossa vitória que é a vitória da democracia e da independência eleitoral". ${ }^{115}$ Naquela mesma data, A Noite informou a existência da "Congregação Política Pró-Eliseu César”, uma espécie de comitê político de apoio ao candidato a deputado pelo Primeiro Distrito. ${ }^{116} \mathrm{Na}$ Praça Tiradentes, ele "foi alvo de uma manifestação de simpatia promovida pelo Centro Republicano Popular. Falou um orador em nome deste Centro e outro em nome da Liga Patriótica Popular e dos operários de fábricas de tecidos". ${ }^{117}$ Também no Largo de

111 Sobre a política no Rio de Janeiro durante a Primeira República, cf. Surama Conde Sá Pinto, Só para iniciados... O jogo político na antiga Capital Federal, Rio de Janeiro: Mauad, 2011.

112 "Cousas da política", Jornal do Brasil, Rio de Janeiro, 17/10/1920, p. 4.

113 “A candidatura de sr. Elyseu Cesar a deputado”, O Combate, São Paulo, 18/12/1920, p. 3.

114 José Murilo de Carvalho, A formação das almas: o imaginário da República no Brasil, São Paulo: Companhia das Letras, 1990.

115 "Uma carta do Sr. Lopes Trovão ao Sr. Elyseu Cesar", O Imparcial, Rio de Janeiro, 30/01/1921, p. 14.

116 "A candidatura Elyseu Cesar", A Noite, Rio de Janeiro, 30/01/1921, p. 4.

117 "Cousas da política”, Jornal do Brasil, Rio de Janeiro, 13/01/1921, p. 6. 
São Francisco houve um "comício popular" a favor de sua candidatura. Durante longo tempo, Vicente Ferreira - uma liderança negra - prendeu a atenção da audiência fazendo propaganda do "sucessor" do José do Patrocínio. ${ }^{118}$ Em termos de sua base de apoio, cabe mencionar ainda as reuniões de "amigos operários admiradores". ${ }^{119}$ No caso da Confederação Geral dos Pescadores do Brasil, a entidade emitiu nota pública, aconselhando aos seus associados eleitores a sufragar no pleito de 20 de fevereiro os nomes daqueles que lhes pareciam em condições de "melhor pugnar pela defesa dos interesses da classe. [...] Para deputado do Primeiro Distrito: Eliseu César". ${ }^{120}$ A partir dos grupos e associações que participaram da mobilização de campanha, depreende-se como segmentos populares, especialmente os trabalhadores, sentiam-se representados por aquela candidatura.

$\mathrm{Na}$ antevéspera das eleições, $A$ Noite publicou uma entrevista com Eliseu César, que justificou a recomendação de seu nome ao eleitorado carioca como obra de "alguns amigos modestos e desinteressados". Segundo o candidato pelo Primeiro Distrito, não faltou político que não tivesse um gesto de descrença quanto à possibilidade de sua vitória no início da campanha. Já se avizinhando ao pleito, esses grandes “entendedores de política" achavam possível seu triunfo: "É que eu tive a fortuna de encontrar simpatias que não falham, vendo o meu nome cercado de elementos emancipados e que estão dispostos à luta para que a minha candidatura seja vitoriosa". Eliseu se mostrava confiante, observando se operar uma "séria modificação no espírito do eleitorado". Quando indagado a respeito de seu programa, respondeu que, se eleito, "não terei outro programa que não seja o da defesa das classes menos favorecidas e dos interesses superiores da República". ${ }^{121}$

Apesar de Eliseu César alentar uma identidade negra e encaminhar demandas no campo dos direitos e da cidadania, seu discurso de campanha não foi abertamente calcado nas questões de raça. Essa postura

118 "Cousas da política", Jornal do Brasil, Rio de Janeiro, 05/02/1921, p. 4.

119 "Cousas da política", Jornal do Brasil, Rio de Janeiro, 18/02/1921, p. 5.

120 “A recomendação da C. G. dos Pescadores do Brasill, A Razão, Rio de Janeiro, 04/02/1921, p. 6.

121 "O Dr. Eliseu César fala-nos da sua candidatura e do seu programa", A Noite, Rio de Janeiro, 18/02/1921, p. 7. 
pode ser lida como estratégia discursiva. Num contexto em que imperava o silêncio em torno das adscrições raciais, defender as "classes menos favorecidas" talvez se tratasse de uma expressão metafórica da qual a população negra fazia parte, ou se valer do discurso universalista - de defesa dos "interesses superiores da República" - talvez consistisse num meio de lutar em prol da igualdade de todos (incluindo "negros" e "brancos") perante a lei, conforme rezava o artigo 72 da Constituição de 1891. Essa retórica desracializada de campanha não impediu que Eliseu fosse visto como catalisador de aspirações e motivações específicas. Para a folha $O$ Combate, ele, "como o falecido deputado Monteiro Lopes, representaria a raça etíope no parlamento nacional". ${ }^{122}$

Eliseu César percorreu distritos, falou em comícios, firmou compromissos, sacrificou parte de suas modestas economias na campanha e fez propaganda até a véspera das eleições. Participou de uma reunião com um grupo de correligionários e simpatizantes, ${ }^{123}$ no entanto seu nome não passou no teste das urnas. Sua votação teria sido insuficiente para sufragá-lo. Desconfiou de irregularidades durante o pleito. Não é para menos. $\mathrm{O}$ estudo clássico de Victor Nunes Leal já apontou que o sistema representativo da Primeira República se caracterizou por escrutínios em que as fraudes e os resultados não expressavam a vontade do eleitor, sendo fruto de manipulações orquestradas pela elite política. As fraudes ocorreriam em todas as fases do processo eleitoral: alistamento de eleitores, votação, apuração dos votos e reconhecimento dos eleitos. ${ }^{124}$ Pesquisas mais recentes, entretanto, têm questionado essa premissa, sob o argumento de que faltam estudos sistemáticos sobre as

122 “O pleito de ontem”, $O$ Combate, São Paulo, 21/02/1921, p. 1. O personagem citado pel'O Combate, Monteiro Lopes (1867-1910), como já mencionado, foi um advogado e político pernambucano, nascido no Recife e falecido na cidade do Rio de Janeiro. Eleito deputado federal pelo Distrito Federal em 1909, depois de ter cumprido mandato no Conselho Municipal, destacou-se pela preocupação com a questão social, sobretudo com os direitos dos trabalhadores. Figura bastante popular na capital da República no início do século XX, é descrito pelo cronista Luís Edmundo como "leader da raça negra, suando reivindicações, a falar, sempre, muito alto, a gesticular como se estivesse discursando", Luís Edmundo, O Rio de Janeiro do meu tempo, Rio de Janeiro: Conquista, 1957, p. 522.

123 "Pró Eliseu César", A Noite, Rio de Janeiro, 19/02/1921, p. 6.

124 Victor Nunes Leal, Coronelismo, enxada e voto: o município e o regime representativo no Brasil, Rio de Janeiro: Forense, 1949. 
fraudes eleitorais. ${ }^{125}$ Seja como for, Eliseu César suspeitou de corrupção no processo de votação e apuração dos votos. Cogitou entrar com uma ação requerendo a anulação das eleições ${ }^{126} \mathrm{e}$ da diplomação de um dos candidatos, ${ }^{127}$ mas acabou desistindo. Um articulista do Jornal do Brasil avaliou que ele conseguira "fazer concorrência aos políticos profissionais, que chegaram a temê-lo, e alcançou uma votação muito além da expectativa", em se tratando de um "candidato novo, sem o apoio de nenhum partido". ${ }^{128}$ Sua postulação à Câmara dos Deputados foi importante, pois, em que pese o insucesso nas urnas, seu nome ficou em evidência, ganhando mais popularidade.

Ao longo do ano de 1921, sobretudo por ocasião de seu aniversário, o "sucessor" do José do Patrocínio recebeu várias homenagens, seja por parte de associações recreativas ${ }^{129}$ e desportivas, ${ }^{130}$ seja por parte de amigos e admiradores: "Não podia ter sido mais expressiva, nem mais brilhante a manifestação de apreço feita ontem, à noite, $[\ldots]$ ao nosso ilustre colega de imprensa e político de grande prestígio no Distrito Federal, Sr. Dr. Eliseu César", registrou o Jornal do Brasil. ${ }^{131}$ Diversos oradores, entre os quais Vicente Ferreira - um ativista negro ligado às causas populares -, renderam-lhe tributos. A manifestação "excedeu à expectativa, tendo a ela se incorporado cerca de quinhentas pessoas, na maioria eleitores do homenageado". ${ }^{132}$

Perseverante, Eliseu se apresentou novamente como candidato "avulso", mas agora ao cargo de intendente municipal -correspondente, hoje, ao de vereador - nas eleições agendadas para o dia 29 de outubro de 1922. Pela repercussão da campanha na imprensa, o candidato pelo

125 Jairo Nicolau, Eleições no Brasil: do Império aos dias atuais, Rio de Janeiro: Zahar, 2012; Paolo Ricci e Jaqueline Porto Zulini, "As eleições no Brasil republicano: para além do estereótipo da fraude eleitoral”, Histórica, n. 63 (2015), pp. 48-58.

126 "Reconhecimentos pacíficos, ou não...", O Paiz, Rio de Janeiro, 22/03/1921, p. 4; “O reconhecimento de poderes da futura Câmara Federal”, O Combate, São Paulo, 23/03/1921, p. 1.

127 "Cousas da política", Jornal do Brasil, Rio de Janeiro, 22/02/1921, p. 4.

128 "Manifestações", Jornal do Brasil, Rio de Janeiro, 12/08/1921, p. 9.

129 "Sociedade F. D. Carnavalesca Embaixadores da Folia", Gazeta de Notícias, Rio de Janeiro, 23/07/1921, p. 5.

130 “Do Liége F. C. no campo do Andarahy A. C.”, O Paiz, Rio de Janeiro, 20/11/1921, p. 7.

131 "Manifestações", p. 9.

132 "Manifestações", Jornal do Brasil, Rio de Janeiro, 13/08/1921, p. 7. 
Primeiro Distrito recebeu várias manifestações de apoio. A Gazeta de Notícias, por exemplo, publicou uma longa nota pública, qualificando Eliseu César como um "ilustre advogado no foro desta Capital", nome sobre o qual recairiam "merecidamente os sufrágios dos eleitores cariocas". Também o identificou como um jornalista dos "mais brilhantes, com uma robusta cultura literária e jurídica". Quer como advogado, quer como orador ou jornalista, ele seria uma "grande figura intelectual, conhecida em todo o país", de modo que as "classes desfavorecidas, sobretudo", encontrariam nele um amigo dedicado. Era "comum vê-lo no júri, a defender, sem remuneração de qualquer espécie, com todo ardor da sua eloquência, os pequenos, a quem o destino conduzia ao banco dos réus". Para a Gazeta de Notícias, era de "individualidades como essa que [se] precisava no Conselho de Intendência Municipal". ${ }^{133}$

[Eliseu César] saberá honrar a sua cadeira, como sincero defensor dos interesses do povo. Diante da sua competência e da sua popularidade, ninguém duvida da vitória do nosso distinto colega no pleito para intendentes. Esta expectativa, aliás, se justifica ante os resultados das últimas eleições para deputados, quando a sua votação teve uma das cifras mais elevadas. ${ }^{134}$

Também pelas páginas da Gazeta de Noticias, o respeitado jornalista Orestes Barbosa conclamou o eleitorado a votar em Eliseu César, mesmo admitindo: "Eu não sou político. Nunca fui. É a primeira vez que tomo a sério um caso eleitoral". ${ }^{135} \mathrm{Na}$ semana final da campanha, correligionários, admiradores e simpatizantes produziram um "manifesto" em favor da candidatura de Eliseu César, no que este respondeu de afogadilho: "confessando-me profundamente grato aos que me honraram levantando em manifesto minha candidatura a uma cadeira de intendente, venho assegurar-lhes que, eleito, procurarei corresponder à confiança popular, sendo, no Conselho, um leal advogado dos interesses da coletividade". ${ }^{136}$ Àquela altura, sua base de apoio parecia se multiplicar. A dois

133 "Notas e notícias", Gazeta de Notícias, Rio de Janeiro, 17/10/1922, p. 1.

134 "Notas e notícias", p. 1.

135 "Elyseu Cesar", Gazeta de Notícias, Rio de Janeiro, 22/10/1922, p. 2.

136 “1 ${ }^{\circ}$ Distrito eleitoral. Aos meus amigos", A Noite, Rio de Janeiro, 16/10/1922, p. 10. 
dias das eleições, Honório Silva, uma liderança negra vinculada à luta dos “contínuos e serventes", publicou n'A Noite uma nota concitando seus companheiros a não se esquecerem de sufragar o nome de Eliseu César, pois seu mandato não obedeceria a "programas irrealizáveis" - aqueles "tão extraordinários que jamais são executados" -, o que redundaria em benefícios à "nossa classe, aos pobres, enfim". ${ }^{137}$

As eleições ocorreram no dia 29 de outubro de 1922. Eliseu foi bem votado, todavia não teve seu nome reconhecido pela comissão verificadora dos poderes - órgão designado pelo Conselho Municipal para conferir e dirimir as controvérsias acerca dos resultados dos escrutínios e proclamar os eleitos. A comissão verificadora recebia de cada junta apuradora dos distritos as atas com a votação final dos candidatos e eventuais contestações dos resultados eleitorais. Em tese, ela procurava garantir a lisura do processo eleitoral, porém, muitas vezes - asseveram os estudos do sistema político da Primeira República -, a comissão assumia caráter político, a serviço dos grupos hegemônicos e não validava o triunfo de candidatos independentes ou ligados a facções políticas minoritárias - tal ato ficou conhecido no meio político da época como "degola". ${ }^{138}$ Fato é que Eliseu César se sentiu injustiçado. Contestou os trabalhos da comissão verificadora sob a alegação de que, entre outras irregularidades, a junta apuradora não teria feito a contagem de votos de algumas seções. Sustentava "ter sido eleito". ${ }^{139}$ Em vão.

Dos candidatos que foram reconhecidos e tomaram posse no Conselho Municipal pelo Primeiro Distrito, nenhum era negro. Talvez por essa razão a FHC publicou um manifesto, denunciando que seu orador oficial fora vítima de uma conspiração arquitetada supostamente por Irineu Machado, senador da República que não escondia seu "ódio à raça negra". Quando o reconhecimento e a diplomação de Eliseu César a todos pareciam um fato "líquido e certo", afirmava o manifesto, eis que Irineu Machado teria articulado e conseguido sua

137 “Eleições municipais", A Noite, Rio de Janeiro, 27/10/1922, p. 7.

138 Nicolau, Eleições no Brasil, pp. 69-70.

139 "As contestações ontem apresentadas sobre as últimas eleições para intendentes", A Noite, Rio de Janeiro, 27/11/1922, p. 3; "Foram impugnados os diplomas dos srs. Brandão e Garcez no $1^{\circ}$. Distrito", Correio da Manhã, Rio de Janeiro, 27/11/1922, p. 3; "O novo Conselho Municipal”, A Noite, Rio de Janeiro, 01/10/1922, p. 3. 
"degola". ${ }^{140}$ Exageros à parte, aquela derrota realmente amargou a vida do "sucessor" do José do Patrocínio com gosto de fel. Altas somas de energia, recursos e esperanças haviam sido empregadas naquele pleito. O sentimento não era outro senão o de que o mérito lhe fora negado. ${ }^{141}$

Tentou retomar sua rotina normal, o que não foi possível, uma vez que veio a óbito no dia 27 de janeiro de 1923, de "síncope cardíaca", ${ }^{142}$ depois de uma "vida intensa, de surpresas e de agitação, na política e no jornalismo, como na advocacia, de empreendimentos sucessivos e muito afanosa". ${ }^{143}$ Eliseu César tinha 51 anos de idade. Segundo os jornais, ele deixou a viúva, D. Bernardina Honorata César, e filhas na "maior pobreza". ${ }^{144}$ Das três filhas (Maria César, Dulce das Rosas César e Honorina César), duas eram casadas.

140 "10 Manifesto", p. 4.

141 A respeito do pleito municipal de 1922 no Rio de Janeiro, Martins Alonso afirma que Eliseu foi vítima de fraude eleitoral: "Ninguém tinha dúvida. Eliseu César estava eleito. Mas, com a trapaça, negaram-lhe o reconhecimento. No lugar do jornalista e advogado eminente, entrava um político sem escrúpulos e semialfabetizado. Naquela noite, quando chegou à casa, acompanhado de seu incomparável amigo jornalista Rolando Pedreira, sentia todo o peso de uma derrota injusta e irreparável, além de se ver preterido por um elemento de cambalachos políticos e que era uma das mais autênticas expressões da mediocridade humana. O velho jornalista vira morrerem todas as suas esperanças. Não resistiu por muito tempo ao abalo", Alonso, Ao longo do caminho, p. 78.

142 "Falecimentos. Dr. Elyseu Cesar", O Paiz, Rio de Janeiro, 28/01/1923, p. 4.

143 "Seu falecimento, hoje, nesta capital", A Noite, Rio de Janeiro, 27/01/1923, p. 5.

144 "A morte do brilhante jornalista e advogado", Gazeta de Notícias, Rio de Janeiro, 28/01/1923, p. 3. Cf. também "Seu falecimento, hoje, nesta capital", A Noite, Rio de Janeiro, 27/01/1923, p. 5. 
Figura 5 - Nota de falecimento do "sucessor" do José do Patrocínio

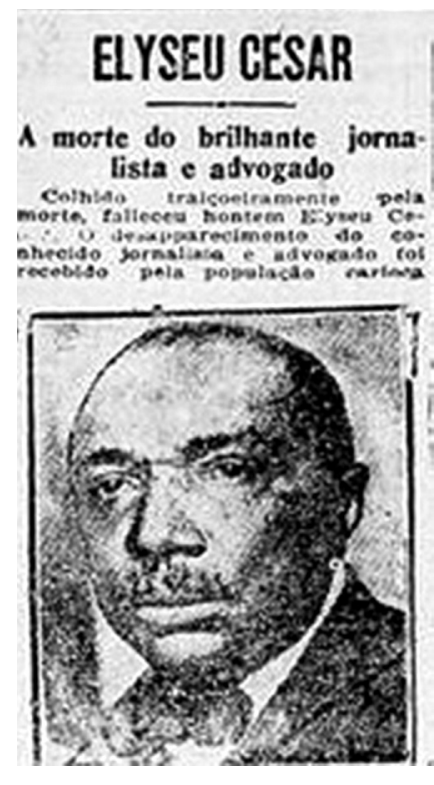

Fonte: Gazeta de Notícias. ${ }^{145}$

"Repercutiu dolorosamente em todas as classes sociais, notadamente na imprensa, a infausta notícia do falecimento do Dr. Elyseu César", salientou o Jornal do Brasil. ${ }^{146}$ "O Rio perdeu há dias, com a morte do Sr. Eliseu César", observou a Gazeta de Notícias, "uma das figuras mais representativas dentre os homens de cor que, pelos seus esforços ou talentos, já se distinguiram no país". ${ }^{147}$ As homenagens póstumas não tardaram.

Cerca de uma semana depois do passamento de Eliseu, a Academia Brasileira de Letras realizou uma sessão na qual Humberto de Campos, o segundo secretário da agremiação, solicitou um voto de condolências pela morte do "escritor paraibano", assinalando, em "comoventes palavras", que o falecido fora um "belo jornalista, na

145 Gazeta de Notícias, Rio de Janeiro, 28/01/1923, p. 3.

146 “A morte do Dr. Elyseu Cesar", Jornal do Brasil, Rio de Janeiro, 03/02/1923, p. 11. Cf. também "O falecimento do Dr. Elyseu Cesar", p. 4.

147 "O historiador dos artistas", Gazeta de Notícias, Rio de Janeiro, 22/02/1923, p. 3. 
Amazônia, de onde viera ultimamente". Vivia no Rio de Janeiro como "intelectual na sombra de uma tímida modéstia. $\mathrm{O}$ voto foi aprovado unanimemente". ${ }^{148}$ Quase duas semanas mais tarde, foi a vez da Associação Brasileira de Imprensa aprovar, em reunião da diretoria, um voto de pesar pelo desaparecimento do associado Eliseu César. ${ }^{149} \mathrm{Na}$ Câmara dos Deputados, Bithencourt da Silva usou a tribuna para homenagear a memória do "saudoso jornalista, político e advogado" paraibano. O parlamentar manifestou seus sentimentos "pela morte do malogrado patrício e companheiro de lutas, fazendo então o elogio do seu talento e espírito de combatedor". Terminou seu discurso requerendo um voto de pesar pelo desenlace de Eliseu César. O requerimento "mereceu aprovação unânime". ${ }^{150}$

A morte daquela figura também reverberou na cidade da Paraíba, sua terra natal. A União, o principal jornal em circulação na época, assim se exprimiu a respeito: "Vítima de uma lesão cardíaca, faleceu o Dr. Elyseu Elias César, um dos paraibanos mais notáveis pelo seu talento e cultura intelectual". A "infausta notícia” teria ecoado em "todas as classes sociais, notadamente na imprensa". ${ }^{151}$

Ao completar o primeiro ano em que o "sucessor" do José do Patrocínio expirou, uma série de homenagens lhe foi feita. ${ }^{152}$ A Associação Nacional dos Artistas Brasileiros promoveu a solenidade de entrega do prêmio "Eliseu César" ao aluno Wilton Pessoa Reinelt, da escola noturna da associação. A solenidade ocorreu no dia 27 de janeiro de 1924 "por ser a data do primeiro aniversário" da morte do saudoso "tribuno popular", tendo feito uso da palavra os professores Dario Muniz de Brito, Rodalante Conti e o jornalista Mário José de Almeida. ${ }^{153}$

148 "Elyseu Cesar", O Brasil, Rio de Janeiro, 05/02/1923, p. 2; “Homenagem", Jornal do Commercio, Rio de Janeiro, 04/02/1923, p. 4.

149 "Associação Brasileira de Imprensa", O Brasil, Rio de Janeiro, 24/02/1923, p. 4.

150 "Homenagem à memória de Elyseu Cesar", O Paiz, Rio de Janeiro, 02/06/1923, p. 7; “Câmara dos Deputados", Jornal do Commercio, Rio de Janeiro, 02/06/1923, p. 1.

151 "Parahyba. A morte do Dr. Elyseu Cesar", Jornal do Brasil, Rio de Janeiro, 03/02/1923, p. 11.

152 "Elyseu Cesar", Gazeta de Notícias, Rio de Janeiro, 27/01/1924, p. 2.

153 "Elyseu Cesar", Jornal do Brasil, Rio de Janeiro, 29/01/1924, p. 6. 
Figura 6 - Homenagem a Eliseu César, realizada pela Federação dos Homens de Cor por familiares, amigos e admiradores no cemitério do Caju por ocasião do primeiro ano de falecimento do saudoso tribuno negro

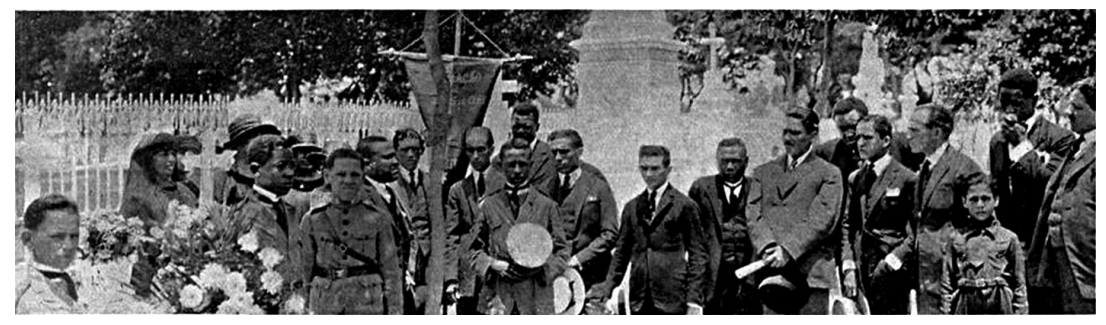

Fonte: O Malho. ${ }^{154}$

O Centro da FHC resolveu homenagear a memória de Eliseu César, seu "inesquecível amigo". No dia 27 de janeiro de 1924, uma comissão da FHC foi ao cemitério São Francisco Xavier, popularmente conhecido como cemitério do Caju, depositar flores no túmulo do "vigoroso polemista", orando nessa ocasião o "Dr. Sabino dos Santos". No dia 28 de janeiro, na igreja de Nossa Senhora do Rosário e São Benedito dos Homens Pretos, estava prevista a celebração de uma "missa em sufrágio da alma do extinto". Para esse ato de "religião e caridade", a FHC convidou a família, os amigos e admiradores do "Dr. Eliseu César". ${ }^{155}$

Segundo o Jornal do Brasil do dia 29 de janeiro, "revestiu-se de grande solenidade a missa mandada rezar pelo Centro Republicano Popular, na Matriz da Candelária, pelo primeiro aniversário da morte do saudoso Dr. Elyseu Elias César". Essa missa foi "bastante concorrida", estando presentes os membros da família do extinto e "grande número de amigos, inclusive associados daquela agremiação política, da qual Eliseu César era presidente e sociofundador". Além dessa cerimônia religiosa, realizaram-se duas missas em sufrágio da alma do malogrado, na igreja de Nossa Senhora do Rosário e na Matriz do Santíssimo Sacramento, a pedido do Centro da Federação dos Homens de Cor e da Associação Nacional dos Artistas Brasileiros, respectivamente. Após esses atos,

154 O Malho, Rio de Janeiro, 09/02/1924, p. 24.

155 "Homenagem do Centro da Federação dos Homens de Cor à memória do Dr. Elyseu Elias Cesar", O Paiz, Rio de Janeiro, 27/01/1924, p. 10; "Elyseu Cesar", Gazeta de Notícias, Rio de Janeiro, 26/01/1924, p. 3. 
"saíram todas as pessoas a eles presentes incorporadas com destino ao cemitério São Francisco Xavier, em romaria ao túmulo de Eliseu César, sendo depositada, naquele local, uma rica coroa de flores naturais". Discursou na ocasião João Baptista do Espírito Santo, "enaltecendo a memória augusta do falecido jornalista". Falou ainda Rodolante Carlos Conti. A viúva de Eliseu e demais parentes foram "muito abraçados pelos presentes, que manifestaram, mais de uma vez, um preito de admiração e de respeito ao valoroso desaparecido". ${ }^{156}$

Em abril de 1924, um grupo de amigos e admiradores do "finado jornalista e advogado", por iniciativa do "conhecido capitalista Sr. Matheus Donadio", articulou-se para adquirir a perpetuidade do carneiro onde repousavam, no cemitério do Caju, os restos mortais do "ilustre homem de letras". ${ }^{157}$ Apesar dos esforços dos amigos e admiradores para manter viva a memória de Eliseu César, seu nome não se perpetuou ao longo do tempo, sendo negligenciado notadamente pelas narrativas históricas. Este artigo é um ponto de partida - e não de chegada - para se descortinar e problematizar a trajetória de um personagem sui generis, que tensionou as possibilidades e os limites da cidadania negra nos umbrais da República e do período pós-abolição.

\section{Considerações finais}

Trajetórias de vida não são paisagens monolíticas do passado. Sua reconstituição permite lançar luz sobre determinado contexto histórico mais amplo - com suas tramas, tensões, relações de dominação, resistências, margens de manobras, nuances -; possibilita identificar as ações de indivíduos em "sistemas normativos, prescritivos e opressores", assim como suas "limitações" e "contradições", porque a "ação social é vista como o resultado de uma constante negociação, manipulação, de escolhas e decisões do indivíduo diante de uma realidade normativa" e de seu próprio funcionamento. ${ }^{158}$ Todavia consideramos importante partir da premissa

156 "Elyseu Cesar", p. 6. Cf. também "Elyseu Cesar". Gazeta de Notícias, Rio de Janeiro, 29/01/1924, p. 2.

157 "Homenagens", Jornal do Brasil, Rio de Janeiro, 11/04/1924, p. 12.

158 Giovani Levi, "Sobre a micro-história", in Peter Burke (org.), A escrita da história: novas perspectivas (São Paulo: Unesp, 1992), pp. 133-161. 
de que as pessoas atuam socialmente sob determinados condicionamentos estruturais que, se não podem ser mudados, sofrem a influência quando não são redefinidos a partir da ação humana. Em última instância, alguns sujeitos singulares conseguem burlar os "sistemas normativos" e nos mostram outras dinâmicas presentes num mesmo panorama histórico, conferindo, assim, um olhar microscópico de aspectos do funcionamento de uma sociedade e a percepção das fissuras do sistema, como ocorreu com Eliseu César, um negro letrado com múltiplas facetas ${ }^{159}$ e ampla atuação no espaço público da época em que viveu.

Amiúde sua vida esteve associada a indivíduos das elites. Na infầncia, recebeu apoio da família paterna, que o criou e o inseriu numa emaranhada rede de parentesco e amizade, cujos desdobramentos em seu itinerário estiveram presentes. Tratando-se dos avós paternos (Vicência Ferreira de Albuquerque e Christiano de Fojos Correia Cézar), percebemos um amplo circuito de sociabilidade, envolvendo pessoas de diferentes clivagens raciais e sociais. No caso do avô, destacamos três momentos em que ele estabeleceu laços de parentesco espiritual apadrinhando o bebê Christiano, filho de "pardos" e batizado em 1840; a criança Guilhermina, filha de "pretos" libertos e batizada em 1851; e os gêmeos Maria e Tito, filhos de "brancos", que receberam o sacramento batismal em 1855. ${ }^{160}$

Essa capilaridade dos avós de Eliseu César nos revela uma rede de sociabilidade e compadrio que favorecia a convivência de pessoas negras com estratos das elites. Considerando os mecanismos de funcionamento da sociedade brasileira oitocentista, as redes de sociabilidade e clientela - baseadas na troca de lealdade e obediência por proteção e

159 Sabrina Loriga nos adverte que, enquanto a "biografia heroica" apresenta como "óbvia uma harmonia entre o particular e o geral", a biografia como problema concebe o singular como um elemento de tensão: "o indivíduo não tem como missão revelar a essência da humanidade; ao contrário, ele deve permanecer particular e fragmentado". Só assim, por meio de diferentes trajetórias individuais, é que se podem romper as homogeneidades aparentes e revelar as contradições que nortearam a formação e edificação de sistemas normativos, nos quais os indivíduos atuam, reproduzindo, adaptando-se ou modificando as relações de poder. Sabina Loriga, "A biografia como problema", in Jacques Revel (org.), Jogos de escala: a experiência da microanálise (Rio de Janeiro: Editora FGV, 1998), pp. 225-249.

160 Os assentos batismais estão, respectivamente, nas páginas dos Livros de Batismo da freguesia Nossa Senhora das Neves, de 1833-1841, fl. 141; 1850-57, fl. 57; e 1857-1863, fl. 31, pertencentes ao Arquivo Eclesiástico da Arquidiocese da Paraíba (AEAPB). 
favores - também eram arenas de fortalecimento de relações políticas e poderiam ser acionadas em diferentes contextos, como nas disputas eleitorais, em vista de apoiar candidaturas vinculadas a um dos "pistolões", ${ }^{161}$ no momento de obter reconhecimento e vantagens na esfera pública, de conseguir algum emprego ou resolver problemas relacionados ao acesso à educação, à justiça e às instâncias de poder institucional e consagração cultural. Eliseu se beneficiou dessas redes de amizades e influências ao longo de sua vida e em diferentes cidades do Brasil.

Em Belém, por exemplo, ele aliou-se a Antônio Lemos, um poderoso político republicano que foi senador e administrador da capital paraense. Seu lema era o mesmo do disposto na bandeira da República Federativa do Brasil: ordem e progresso. Por mais de uma década, Eliseu vivenciou as palpitantes contendas políticas da Belle Époque amazônica. Assumiu secretaria de governo e mandato no Legislativo Estadual, sem falar que militou na imprensa em defesa da consolidação do sistema republicano em terras nortistas. Já no Rio de Janeiro, continuou acreditando no republicanismo como símbolo do vicejar de uma nova era, de alargamento de direitos e cidadania, porém colecionou desventuras em suas investidas na esfera pública. Talvez ele não dispusesse, ali, de suficiente capital simbólico e político, nem amealhava uma sólida rede de sociabilidade e compadrio que permitisse concretizar seus novos projetos de vida, que passava por atuar no Parlamento Federal ou no Legislativo Municipal.

Não foi a primeira e tampouco a única vez que ele enfrentou desafios a toda prova. Afinal, tinha a epiderme escura e os ditames do racismo, fosse o "científico" ou o "popular", teimavam em considerar os indivíduos de seu grupo racial como inferiores. ${ }^{162}$ Afora isso, nasceu e cresceu numa sociedade escravista, embora não tivesse vínculos diretos com o cativeiro. Enveredando-se num campo de possibilidades, Eliseu

161 Richard Graham, Clientelismo e política no Brasil do século XIX, Rio de Janeiro: Editora UFRJ, 1997.

162 Dain Borges, “Puffy, ugly, slothful, and inert': degeneration in Brazilian social thought, 1880-1940", Journal of Latin American Studies, v. 25, n. 2 (1993), pp. 235-256; Lilia Moritz Schwarcz, O espetáculo das raças: cientistas, instituições e questão racial no Brasil, São Paulo: Companhia das Letras, 1993; Elias Thomé Saliba, Raizes do riso: a representação humorística na história brasileira - da Belle Époque aos primeiros tempos do rádio, São Paulo: Companhia das Letras, 2002, pp. 112-124. 
escolheu uma estratégia de inserção fundada em dois pilares: capital cultural e rizoma. Parece ter sido a mediação intelectual (práticas culturais e ação política) nas redações dos jornais, nos tribunais do júri, nas plenárias do parlamento e nas associações civis uma espécie de "forja diaspórica" na qual apurou e depurou um empenhado poder simbólico, nas duas dimensões de sua experiência: a "pena" e a palavra. Para além de uma raiz única, sua identidade foi balizada por rotas e rizomas dos imponderáveis da luta de um fazer-se histórico sempre em movimento de relações com a diversidade. Isso ocorreu graças aos frequentes deslocamentos e reterritorializações no decorrer da vida, por diferentes regiões do Brasil. Pode-se inferir que, no limite, ele levou uma vida em trânsito, errante, diaspórica, entrelaçando fluxos, trocas e agenciamentos de ideias, expectativas e experiências movediças, descontínuas, intervalares e multidirecionais. Com vocação rizomática, brotou, arborizou-se e ramificou-se por hastes subterrâneas que se espalharam e formaram bulbos por onde passou, ocupando os interstícios dos espaços cultivados. ${ }^{163}$

Mas vale assinalar que Eliseu não foi o único afro-brasileiro que conquistou visibilidade no período. Conforme a historiografia recente tem evidenciado, outras figuras desse segmento populacional, com atuação ativa na Primeira República - período de reordenamento social, de reconfigurações das hierarquias raciais e de disputas dos projetos de nação -, também se destacaram na cena política e cultural. Como exemplo, os baianos Manuel Querino ${ }^{164}$ e Alfredo Casemiro da Rocha; ${ }^{165}$ o maranhense

163 Paul Gilroy, O Atlântico negro; Gilles Deleuze e Félix Guattari, Mil Platôs, São Paulo: Editora 34,2012 , v. 5.

164 Maria das Graças de Andrade Leal, Manuel Querino entre letras e lutas - Bahia: 1851-1923, São Paulo: Annablume, 2009.

165 Oracy Nogueira, Negro político, político negro: a vida do doutor Alfredo Casemiro da Rocha, parlamentar da "República Velha", São Paulo: Edusp, 1992; James Woodard, "Negro político, sociedade branca: Alfredo Casemiro da Rocha como exceção e estudo de caso (São Paulo, décadas de 1880 a 1930)", in Flávio Gomes e Petrônio Domingues (orgs.), Políticas de Raça: experiências e legados da abolição e da pós-emancipação no Brasil (São Paulo: Selo Negro, 2014), pp. 231-261. 
Hemetério dos Santos; ${ }^{166}$ o pernambucano Monteiro Lopes; ${ }^{167}$ o gaúcho Aurélio Veríssimo de Bittencourt; ${ }^{168}$ o mineiro Benjamim de Oliveira; ${ }^{169}$ os cariocas Evaristo de Moraes, ${ }^{170}$ Eduardo das Neves ${ }^{171}$ e Lima Barreto $;{ }^{172}$ entre outros que debateram e disputaram os diferentes projetos de política, cultura e identidade nacional, e foram reconhecidos em vida, mas aos poucos caíram na galeria do preterimento, do ostracismo, da subestimação ou simplesmente jazeram nos desvãos da memória após a morte.

Seja como for, a trajetória de Eliseu César permite visualizar outras imagens, representações e narrativas de pessoas negras, diferentes daquelas propaladas por estudos acadêmicos de outrora, que identificavam esses sujeitos como anômicos e bestializados; seres incapazes, seja de autorrealização ou de enfrentamento proativo às adversidades da vida. Quando colocamos o percurso de Eliseu em tela, depreendemos aspectos do protagonismo negro de um sujeito que, embora tenha sofrido na pele os achaques típicos das relações de dominação e dos estigmas do cativeiro no período pós-abolicionista, não sucumbiu à "metafísica da raça". Nos limites do possível, impôs-se (ou tentou se impor) a partir do "talento", ${ }^{173}$ da perseverança, da astúcia e da habilidade para se apropriar e incidir no jogo social, cultural e político de seu tempo, mostrando-nos como a experiência afro-diaspórica é complexa, ambígua e multifacetada.

166 Maria Lúcia Rodrigues Müller, A cor da escola: imagens da Primeira República, Cuiabá: Editora UFMT, 2008; Luara dos Santos Silva, “'O negro nunca foi estúpido, fraco, imoral ou ladrão': Hemetério José dos Santos, identidade negra e as questões raciais no pós-Abolição carioca (1888-1920)", in Martha Abreu, Giovana Xavier, Lívia Monteiro e Eric Brasil (orgs.), Cultura negra: Festas, carnavais e patrimônios negros (Niterói: EdUff, 2018), pp. 266-296.

167 Carolina Vianna Dantas, "Monteiro Lopes (1867-1910): um líder da raça negra na capital da República", Afro-Ásia, n. 41 (2010), pp. 167-209; Domingues, "'Vai ficar tudo preto"”.

168 Paulo Roberto S. Moreira, "Aurélio Veríssimo de Bittencourt: burocracia, política e devoção", in Flávio Gomes e Petrônio Domingues (orgs.), Experiências da emancipação: biografia, instituições e movimentos sociais no pós-abolição (1890-1980) (São Paulo: Selo Negro, 2011), pp. 83-107.

169 Erminia Silva, Circo-teatro: Benjamim de Oliveira e a teatralidade circense no Brasil, São Paulo: Altana, 2007.

170 Mendonça, Evaristo de Moraes, tribuno da República.

171 Martha Abreu, "O 'crioulo Dudu’: participação política e identidade negra nas histórias de um músico cantor (1890-1920)”, Topoi, v. 11, n. 20 (2010), pp. 92-113.

172 Lilia Moritz Schwarcz, Lima Barreto: triste visionário, São Paulo: Companhia das Letras, 2017.

173 Ascendino Leite, "O pardo Elyseu Cesar", in Anuário da Parahyba (João Pessoa: Imprensa Oficial, 1935), pp. 65-69. 


\title{
Recebido em 9/1/2018 e aprovado em 12/12/2019
}

\section{Resumo}

O artigo reconstitui fragmentos da vida de Eliseu Elias César (1871-1923), um intelectual afro-diaspórico que circulou por diferentes regiões do Brasil. Em todas elas, manteve uma vida profissional polivalente, desenvolvendo seus "talentos" como advogado, jornalista, político, poeta e orador. Procura-se destacar as experiências proativas de um negro que se apropriou das "artes de dizer" pela escrita e oralidade, assim como pela ação política e agência associativa, travando embates na esfera pública e participando de governo e grupos republicanos. A trajetória de Eliseu César sugere a importância de revisitar as interpretações históricas que subestimaram ou mesmo negligenciaram o papel do negro na cena histórica republicana. Assim, ao descortinar e problematizar aspectos da vida desse personagem, o artigo procura lançar luz sobre as complexidades, tensões, lutas e ambiguidades relacionadas à afirmação da cidadania negra no Brasil pós-abolição.

Palavras-chave: negro - intelectual - afro-diáspora - Primeira República - pós-abolição.

\begin{abstract}
This article retraces fragments of Eliseu Elias César's life (1871-1923), an Afro-Diasporic intellectual who traveled around different regions of Brazil. He had a multipurpose professional life and developed his talents as lawyer, journalist, politician, poet and spokesman. Moreover, this paper highlights the proactive experiences of a black man who appropriated the "art of lecturing" through his writing and oral skills, as well as his political actions and associative agencies. He stroke the public sphere and took part in government and republican groups. Elisha Caesar's path suggests the importance of reviewing the historical interpretations that underestimated, or even neglected, the role of black people in the republican historical scene. Thus, by uncovering and problematizing aspects of this character's life, the article seeks to shed light on the complexity, tensions, struggles and ambiguities in the standing of black citizenship in post-abolition Brazil.
\end{abstract}

Keywords: blackness - intellectual-afro-diaspora-First Republic-post-abolition. 